\title{
Turning a Shove into a Nudge? A "Labeled Cash Transfer" for Education"
}

\author{
By Najy Benhassine, Florencia Devoto, Esther Duflo, \\ Pascaline Dupas, and Victor Pouliquen*
}

\begin{abstract}
Conditional Cash Transfers (CCTs) have been shown to increase human capital investments, but their standard features make them expensive. We use a large randomized experiment in Morocco to estimate an alternative government-run program, a "labeled cash transfer" (LCT): a small cash transfer made to fathers of school-aged children in poor rural communities, not conditional on school attendance but explicitly labeled as an education support program. We document large gains in school participation. Adding conditionality and targeting mothers made almost no difference in our context. The program increased parents' belief that education was a worthwhile investment, a likely pathway for the results. (JEL H23, I24, 128, I38, $\mathrm{J} 24, \mathrm{O} 15, \mathrm{O} 18$ )
\end{abstract}

This paper evaluates the impact of a "labeled cash transfer" (LCT). The program we evaluate features small transfers, targeted to poor communities (with all households eligible in those communities), and paid out to fathers. The program is unconditional but retains an implicit endorsement of education through its school-based enrollment procedure. This program was designed and implemented on a (randomized) pilot basis by Morocco's Ministry of Education. Within the same experiment, conducted over 600 communities, we compared it to three variants: (i) making the transfer explicitly conditional on regular attendance, (ii) making payments to mothers instead of fathers, and (iii) doing both at the same time.

\footnotetext{
* Benhassine: The World Bank, 1818 H St. NW Washington, DC 20433 (e-mail: nbenhassine@ worldbank.org); Devoto: Paris School of Economics, 48 boulevard Jourdan, 75014 Paris, France and Abdul Latif Jameel Poverty Action Lab (JPAL) (e-mail: fdevoto@povertyactionlab.org); Duflo: Department of Economics, Massachusetts Institute of Technology (MIT), 50 Memorial Drive, Cambridge MA 02142 and National Bureau of Economics (NBER) (e-mail: eduflo@mit.edu); Dupas: Stanford Department of Economics, 579 Serra Mall, Stanford CA 94305 and NBER (e-mail: pdupas@ @tanford.edu); Pouliquen: Paris School of Economics 48 boulevard Jourdan, 75014 Paris, France and JPAL (e-mail: vpouliquen@povertyactionlab.org). The protocol for this study was approved by the IRBs of Dartmouth College, MIT, and University of California, Los Angeles (UCLA). We thank the Moroccan Ministry of Education and the Council for Higher Education for their collaboration, as well as the World Bank, the Spanish Impact Evaluation Fund, the Gender Action Plan, the Korean Trust Fund for ICT4D (InfoDev), the multidonor trusts fund Governance Partnership Facility, and JPAL at MIT for funding. We are grateful to Bénédicte de la Brière and Rebekka Grun from the World Bank for their expert support and to Claire Bernard, Nada Essalhi and Aurélie Ouss from IPA Morocco for outstanding field research assistance. We thank anonymous referees, George Bulman, Jishnu Das, Brian Jacob, Paul Glewwe, Dan Silverman, Hongliang Zhang, and numerous seminar participants for insightful comments. The findings, interpretations, and conclusions expressed in this work do not necessarily reflect the views of the World Bank, its Board of Executive Directors or the governments they represent. All errors are our own.

Go to http://dx.doi.org/10.1257/pol.20130225 to visit the article page for additional materials and author disclosure statement $(\mathrm{s})$ or to comment in the online discussion forum.
} 
A large body of rigorous evidence, based on CCT programs implemented around the world over the last 15 years, demonstrates their ability to affect households' investments in education and health (see Fizbein et al. (2009) for a review and Saavedra and García (2012) for a recent meta-analysis). A potential drawback of CCTs as currently designed, however, is that two of their standard features, targeting (typically, individual level proxy-means testing) and conditionality, make them expensive to administer. These two features have been estimated to account for 60 percent of the administrative costs of PROGRESA (Caldés, Coady, and Maluccio 2006), 49 percent of the costs for PRAF in Honduras, and 31 percent for RPS in Nicaragua.

A further drawback of both targeting and conditionality is that they have the potential to lead to the exclusion of the people that policymakers would most like to aid. This has not been systematically studied in many CCTs, but some studies have focused specifically on these issues. In a study designed to compare targeting mechanisms in Indonesia, Alatas et al. (2012a) find that a proxy-means test mimicking the government's standard practice incorrectly excluded 53 percent of truly poor households (based on their consumption level) from the list of beneficiaries for a large cash assistance program, while it incorrectly included 20 percent of nonpoor households. In Malawi, under a program whose ultimate goal was to improve female adolescent health, and where the conditionality was found to increase school attendance, girls who dropped out of school and lost their cash transfer eligibility transitioned into marriage and childbearing faster than comparable girls sampled for unconditional transfers (Baird, McIntosh, and Özler 2011). Conditionality could also reduce the effectiveness of transfer programs by discouraging some households to even apply for them.

Yet, both targeting and conditionality play important roles in existing CCT programs. First, targeting is critical because transfers are in part redistributive, and it would not be feasible within the budgets of developing countries to provide all citizens with unconditional transfers worth 20 percent of a poor household's consumption (to take the example of the first CCT program, Mexico's PROGRESA). Regarding conditionality, several recent studies have shown that the incentives that conditionality (or at least perceived conditionality) give to parents may have an additional impact on educational investments, beyond the pure income effect that comes about from unrestricted cash transfers (see Baird et al. 2013, for a review).

Given this tension between the costs and benefits of targeting and conditionality, a natural question is whether it is possible to retain at least some of the human capital benefits of CCTs through a much more limited program. Under the standard economic theory underlying CCTs, conditionality provides economic incentives for households, but those should only have bite if the programs are sufficiently large that the households stand to lose something if they do not comply. At the same time, there is evidence that even small conditional transfers have positive effects on human capital investment (see Banerjee et al. (2010) on incentives for vaccinations, and Filmer and Schady (2008) on the impact of a small CCT in Cambodia). This suggests that economic incentives may not be the only factor at play in CCT. In other words, a "nudge" may be sufficient to significantly increase human capital investment, while CCTs as currently designed provide a big shove. By offering a 
small cash transfer and tying it loosely to the goal of education, a government may be able to make the importance of education salient and increase the demand for it even without formal incentives. A small cash transfer would not need to be targeted at the household level, since the budgetary implications of inclusion errors (giving it to less poor people) would not be large, and if the explicit incentives are replaced by an implicit endorsement, this removes the need for monitoring.

We evaluate such a program in Morocco. Morocco is a lower middle income country, with a GDP per capita estimated at $\$ 3,000$ in 2011 (\$5,100 in PPP terms). Education levels in the general population are still relatively low, with only about 67 percent of the adult population literate as of 2012 according to UNICEF estimates. As of academic year 2007/2008, the year preceding the introduction of the pilot program we examine here, the Ministry of Education estimated that over 90 percent of rural children started primary school, but 40 percent dropped out before completing the full six years of primary education, and the government became concerned about improving enrollment and retention in school. We were contacted by the government of Morocco who wanted our help in conducting an evaluation of a new CCT program, Tayssir, aimed at increasing the rural primary school completion rate. They had in mind a small transfer to households with children aged 6-15, conditional on enrollment and attendance, paid out to fathers, ${ }_{1}^{1}$ and targeted at the community level (meaning all households with eligible children in targeted communities could receive the transfer). The transfer amount increased with age/grade but remained modest: the average annual transfer per household equaled about 5 percent of their annual expenditures (for comparison, CCTs in other countries have ranged from 6 to 25 percent of household expenditures). We proposed to add two components to the planned evaluation: compare it to an unconditional component, and compare it to a more standard version where transfers are given to mothers. To ensure that the unconditional program would still be framed as an education intervention, the Ministry of Education (the Ministère de l'Education Nationale, or MEN) proposed that, even for children who were not enrolled in school, the enrollment for Tayssir would be done at schools and by headmasters, with an effort to mobilize all children, even those currently not enrolled. The program was thus a "labeled" cash transfer (LCT), explicitly tied to an education goal but without formal requirements on attendance or enrollment. The fact that the program was run from schools, however, may have discouraged or even excluded families who had never had any prior contact with the school system.

Over 320 school sectors (with at least two communities each) were randomly assigned to either a control group or one of four variants of the program: LCT to fathers, LCT to mothers, CCT to fathers, and CCT to mothers. Using objective measures of school participation (collected through surprise school visits by the research team) for over 44,000 children, and detailed survey data for over 4,000 households, including households whose children were out of school before the program began, we find large impacts of cash transfers on school participation under all versions of

\footnotetext{
${ }^{1}$ In the Moroccan context, where it is commonly men who handle money, go to weekly markets to do most purchases and sales, and travel out of the village alone, paying out to fathers was perceived by the Ministry of Education as much less constraining than paying out to mothers and was seen as the "normal" way to proceed.
} 
the program, and very little difference in impacts between transfers made to mothers and those made to fathers. Over two years, the LCT reduced the dropout rate by 76 percent among those enrolled at baseline; increased re-entry by 82 percent among those who had dropped out before the baseline; and cut the share of never-schooled by 31 percent. The LCT had modestly positive, though insignificant, impacts on math scores. While the CCT also had a large positive effect on school participation, explicitly conditioning transfers on attendance, if anything, decreased their impact in the context of this program, particularly on re-enrollment of children who had initially dropped out, and generally on children with lower probability to re-enroll or stay in school. A limitation of our sampling frame is that we do not observe children from households who had never enrolled any child in school as of July 2008. There seem to be relatively few of those households, however: we estimate that at most 4.5 percent of children in rural areas lived in families who had never enrolled any child.

Note that the comparison between LCT and CCT tells us little about the question that other papers in the literature have addressed, namely how an unconditional, unlabeled cash transfer program would compare to a CCT. Instead, we study a program where transfers are not conditioned on school participation but school enrollment is strongly encouraged. Indeed, because registration for both the LCT and the CCT was done by school headmasters on the school compound, one reason behind the large impacts of the LCT seems to be that it increased the salience of education as much as the CCT. By the end of the second year, parents' beliefs about the returns to education had increased in all groups, and so had their beliefs about the quality of the local school, even though neither of these two dimensions was affected by the cash transfers. This is consistent with parents interpreting the introduction of a pro-education government program, whether it formally requires regular school participation or not, as a signal that education is important. In line with this, in all groups, there was a large reduction in dropouts reported due to "child not wanting to attend school" and to "poor school quality."

Our results also bring attention to the fact that complex government programs may not always be understood easily, and therefore some of the expected benefits of imposing rules (e.g., conditionality) can be lost in implementation. We took care in our data collection to elicit beliefs regarding the rules governing the cash transfer programs. While teachers had a relatively good understanding of the program in their specific community, among parents we see only minor differences between CCT and LCT communities, in both years 1 and 2, in how the programs were perceived. In the first year, in both groups about 50 percent of the parents thought the transfers were conditional on attendance. We thus cannot reject that parents in either group had no idea and just guessed when asked about conditionality. By the second year, over 80 percent of parents in the LCT communities had understood that the program was unconditional; but most parents in the CCT communities also perceived transfers as unconditional, most likely because absence rates are low in Morocco, and few children saw their transfers docked. Thus the gap in perceived conditionality between LCT and CCT, while statistically significant at the end of year 2, was less than 5 percentage points. This could explain why we see little impact of adding conditionality above and beyond labeling, and in the long run, CCT and LCT 
may have different effects once the conditionality is better understood. Importantly, however, the fact that school participation impacts stayed large for both LCT and CCT programs in year 2, when a great majority of parents believed transfers were not conditional on attendance, implies that the confusion regarding the rules is not the reason behind the success of the LCT, even if they explain the lack of even more success of the CCT.

Overall, our results suggest that cash transfer programs may work in part by changing how parents perceive education. Of course, much larger transfers may have even larger effects on education, particularly if they are conditional and stringent (as the previous studies looking at the impact of conditionality have found). But just changing perceptions seems to be getting a long part of the way. This is consistent with the recent literature showing that the perceived returns to education are an important determinant of the demand for education, but in developing countries, information about these returns is often imperfect (Jensen 2010; Jensen 2012; Kaufmann 2012; Nguyen 2008).

\section{Background and Experimental Design}

\section{A. Conditional Cash Transfers: A Short Review of the Literature}

A number of recent studies have focused on the importance of conditionality. De Brauw and Hoddinott (2011) exploit the fact that PROGRESA, due to administrative issues, made unconditional transfers to a set of beneficiaries to compare educational outcomes of both groups. They find no effect of conditionality on the likelihood that children attend primary school, but a significant difference among those making the transition from primary to secondary school. Barrera-Osorio et al. (2011) find that making transfers conditional on secondary school graduation significantly improves educational achievement. ${ }^{2}$

The two existing randomized studies comparing CCTs and Unconditional Cash Transfers (UCTs) that we are aware of have nuanced results. Baird, McIntosh, and Özler (2011) run an experiment to compare a CCT to a UCT in Malawi between 2007 and 2009. They find that conditioning cash transfers on school attendance increases the effectiveness of the program at keeping adolescent girls in school, but decreases its effectiveness at averting teen pregnancy and marriage. Akresh, de Walque, and Kazianga (2013) compare a UCT to a CCT conditional on enrollment in Burkina Faso. Overall, they find no significant difference between the UCT and the CCT. They argue that CCTs lead to larger impacts than UCTs among girls and initially out of school children, but the effects of the UCT remain statistically significant even for children who were initially out of school.

\footnotetext{
${ }^{2}$ Conditionality has also been shown to matter for health behavior outcomes. Attanasio, Oppedisano, and VeraHernández (2013) estimate that, in the Colombian program Familias en Acción, children would receive 86 percent less preventive care visits if the program was not conditional on these visits.
} 


\section{B. Labeling: Definition and Evidence}

Our study compares conditional cash transfers to cash transfers that are unconditional but labeled as being a child education benefit. Under standard models of decision-making, such labeling should have no bearing on how the money is spent-it should be fully fungible with other income sources. The behavioral economics literature suggests that labeling could matter, however, if it facilitates mental accounting (Thaler 1990): parents may consider the labeled child benefit as entering into a mental education account, not fungible with other accounts. Edmonds (2002) test for the presence of such labeling effect in the context of a child benefit in Slovenia and finds no evidence for it. In our context, the labeling could matter not just through mental accounting, however. It could (and we will show it will) be interpreted by parents as a signal on the value of education. The labeling effect in this case could have an information effect, within the standard model of demand for education.

\section{Experimental Design}

Tayssir was targeted at the geographic level. The pilot took place in the 5 poorest regions of Morocco (out of 16 administrative regions), and within those regions, in the poorest rural municipalities (administrative units called "communes" in Morocco) with high dropout rates at the primary school level. ${ }^{3}$ A total of 320 rural primary school sectors (close to 65 percent of all school sectors in the selected regions) were sampled for the study in those municipalities. Each rural school sector has a well-identified catchment area validated by the Delegation de l'Education Nationale, the provincial-level authority for education policy. A school sector includes a "main" primary school unit and several "satellite" school units (four on average). Satellite units fall under the authority of the headmaster of the main unit, and sometimes offer only lower grade classes.

Figure A1 summarizes the experimental design. Out of the 320 school sectors in the study, 260 were randomly selected to participate in the Tayssir pilot program. These school sectors constitute the treatment group. The other 60 sectors in the sample were selected to constitute the comparison group. ${ }^{4}$ The 260 school sectors in the treatment group were subdivided randomly into 4 subgroups, with a two-by-two design: simply labeled as designed to facilitate educational investments ("Tayssir" means facilitation in Arabic) versus conditional on attendance; and father-beneficiary versus mother-beneficiary. The groups were not even in size: while the father versus mother split was 50\%-50\%, the labeled versus conditional split was 31\%-69\%.5 School sectors participating in the pilot program were selected such that they would be relatively far from each other (on average they are 6 kilometers apart), which limited the risk that parents transferred their children from control to treatment schools or from CCT to LCT schools, as well as other forms of externalities.

\footnotetext{
${ }^{3}$ The regions are Marrakech-Tensift-Al Haouz, Meknès-Tafilalet, l'Oriental, Souss-Massa-Draa and Tadla-Azilal.

${ }^{4}$ The randomization was stratified by region, school size, dropout rate, and by whether the government was planning to make improvements to school infrastructure within the two-year time frame of the evaluation.

${ }^{5}$ We initially planned to evaluate the impact of different strength of monitoring of presence but these subtreatments were not reliably implemented, and we don't analyze them.
} 
Two school sectors (one in the control group and one in the treatment group) had to be dropped after the randomization because floods rendered them completely inaccessible to the research team during baseline, leaving us with a final sample of 318 school sectors. Thus, we ultimately have 59 schools in the control group, 40 school sectors in the LCT-to-fathers group, 40 school sectors in the LCT-to-mothers group, 90 schools sectors in the CCT-to-fathers group, and 89 school sectors in the traditional-style CCT-to-mothers group. Table 1 presents summary statistics for schools in the control sample (column 1), differences between the control group and the LCT-to-fathers group (column 2), as well as differences between the LCT-to-fathers group and the three variants with added components (columns 3-5). ${ }^{6}$ Schools in the sample are relatively small, with an average enrollment in grades 1 to 5 of only 77 pupils. Over 60 percent of classes are taught in multi-grade groups. Only 42 percent of the students are girls. Overall, the control and LCT-to-fathers groups appear relatively well balanced with respect to observable characteristics: 1 out of 12 of the differences estimated are significant at the 10 percent level. In the analysis, we control for the baseline school characteristics that are imbalanced at baseline (remoteness and electricity) as well as student characteristics (age and gender). The control variables do not affect the results.

\section{The Tayssir Cash Transfer Program}

The Tayssir program consisted of cash payments to parents of primary school age children (6 to 15). The cash allowance was increasing with age, starting from 60 Moroccan dirhams (MAD) per month ( $\sim 8$ in 2008 USD) per child old enough for grades 1 or 2 (6-7 years old), to 80 MAD per month ( $\sim 10$ USD) per child old enough for grades 3 and 4 ( $8-9$ years old), to 100 MAD per month ( 13 USD) per, child old enough for grades 5 and 6 (10-11 years old). Thus, for young children the cash allowance for a year (10 school months) was up to $600 \mathrm{MAD}$, and for the older children it was up to 1,000 MAD. This compares favorably to (very modest) yearly schooling expenditures, reported at $180 \mathrm{MAD}$ on average per child in primary school in our control group. But the transfers are very small compared to most CCTs: the monthly transfer for a child in grade 3 to 4 , for example, represents 2.7 percent ( 3 percent) of the mean (median) monthly household consumption in our sample (and still only 6.3 percent of the monthly consumption of households at the fifth percentile). The transfer that the average household was eligible for represented 5 percent of the average monthly consumption. In contrast, the range for traditional CCTs is between 6 percent and 27 percent of mean monthly household consumption (Fizbein et al. 2009). In PROGRESA, the average transfer for grade 3 to grade 6 was $\$ 14$, and the total monthly average transfer received by households

\footnotetext{
${ }^{6}$ This table follows the same format as the main regression tables below. As explained in more detail in Section III, column 2 presents estimates on the differential characteristics for schools sampled in the LCT-to-fathers group compared to control group schools. Columns 3-5 present estimates on the differential effect of the three other treatment groups compared to the LCT-to-fathers group, along with the total effects $p$-values for test of equality between LCT and CCT, and mothers versus fathers.
} 
Table 1 -School Level Characteristics at Baseline: Balance Check

\begin{tabular}{|c|c|c|c|c|c|c|c|c|}
\hline & \multirow[b]{2}{*}{$\begin{array}{c}\text { Mean in } \\
\text { control } \\
\text { group } \\
(1)\end{array}$} & \multirow{2}{*}{$\begin{array}{c}\text { Difference } \\
\text { between LCT } \\
\text { to fathers } \\
\text { and } \\
\text { control } \\
(2)\end{array}$} & \multicolumn{3}{|c|}{$\begin{array}{c}\text { Difference between }[\ldots] \text { and } \\
\text { LCT to fathers }\end{array}$} & \multirow[b]{2}{*}{$\begin{array}{l}\text { Obs. } \\
(6)\end{array}$} & \multirow{2}{*}{$\begin{array}{l}p \text {-value } \\
\text { for CCT } \\
\text { different } \\
\text { from } \\
\text { LCT } \\
(7)\end{array}$} & \multirow{2}{*}{$\begin{array}{l}p \text {-value } \\
\text { for mother } \\
\text { different } \\
\text { from father } \\
\quad(8)\end{array}$} \\
\hline & & & $\begin{array}{l}\text { LCT to } \\
\text { mothers } \\
\text { (3) }\end{array}$ & $\begin{array}{l}\text { CCTs to } \\
\text { fathers } \\
\text { (4) }\end{array}$ & $\begin{array}{l}\text { CCTs to } \\
\text { mothers } \\
(5)\end{array}$ & & & \\
\hline Total enrollment & $\begin{array}{c}77.402 \\
{[57.468]}\end{array}$ & $\begin{array}{l}-2.826 \\
(5.504)\end{array}$ & $\begin{array}{c}5.094 \\
(6.258)\end{array}$ & $\begin{array}{c}-1.818 \\
(5.036)\end{array}$ & $\begin{array}{c}0.938 \\
(5.028)\end{array}$ & 627 & 0.398 & 0.345 \\
\hline $\begin{array}{l}\text { Share of grades that are } \\
\text { taught in multigrade } \\
\text { classes }\end{array}$ & $\begin{array}{c}0.611 \\
{[0.399]}\end{array}$ & $\begin{array}{c}-0.012 \\
(0.05)\end{array}$ & $\begin{array}{l}0.005 \\
(0.057)\end{array}$ & $\begin{array}{l}0.02 \\
(0.047)\end{array}$ & $\begin{array}{c}-0.035 \\
(0.047)\end{array}$ & 627 & 0.761 & 0.197 \\
\hline $\begin{array}{l}\text { Average number of sections } \\
\text { per grade }\end{array}$ & $\begin{array}{c}1.305 \\
{[0.344]}\end{array}$ & $\begin{array}{c}-0.006 \\
(0.048)\end{array}$ & $\begin{array}{c}0.062 \\
(0.057)\end{array}$ & $\begin{array}{c}0.002 \\
(0.045)\end{array}$ & $\begin{array}{c}-0.006 \\
(0.046)\end{array}$ & 627 & 0.313 & 0.685 \\
\hline Average age & $\begin{array}{c}9.636 \\
{[0.589]}\end{array}$ & $\begin{array}{c}0.094 \\
(0.074)\end{array}$ & $\begin{array}{c}-0.089 \\
(0.086)\end{array}$ & $\begin{array}{c}0.005 \\
(0.063)\end{array}$ & $\begin{array}{l}-0.111 \\
(0.059)^{*}\end{array}$ & 610 & 0.885 & $0.03 * *$ \\
\hline Share of female students & $\begin{array}{c}0.422 \\
{[0.111]}\end{array}$ & $\begin{array}{c}0.007 \\
(0.018)\end{array}$ & $\begin{array}{c}0.014 \\
(0.02)\end{array}$ & $\begin{array}{l}0.01 \\
(0.016)\end{array}$ & $\begin{array}{c}0.015 \\
(0.016)\end{array}$ & 612 & 0.663 & 0.468 \\
\hline Students-teacher ratio & $\begin{array}{l}21.698 \\
{[9.566]}\end{array}$ & $\begin{array}{c}-0.137 \\
(1.149)\end{array}$ & $\begin{array}{l}0.315 \\
(1.3)\end{array}$ & $\begin{array}{c}-0.432 \\
(1.087)\end{array}$ & $\begin{array}{c}-0.603 \\
(1.057)\end{array}$ & 612 & 0.36 & 0.983 \\
\hline $\begin{array}{l}\text { Teachers presence rate } \\
\text { during baseline surprise } \\
\text { visit }\end{array}$ & $\begin{array}{c}0.794 \\
{[0.379]}\end{array}$ & $\begin{array}{l}0.109 \\
(0.05)^{* *}\end{array}$ & $\begin{array}{r}-0.065 \\
(0.06)\end{array}$ & $\begin{array}{c}-0.072 \\
(0.046)\end{array}$ & $\begin{array}{r}-0.072 \\
(0.049)\end{array}$ & 600 & 0.283 & 0.601 \\
\hline $\begin{array}{l}\text { Students presence rate } \\
\text { during baseline surprise }^{\text {visit }}\end{array}$ & $\begin{array}{c}0.926 \\
{[0.141]}\end{array}$ & $\begin{array}{l}0.026 \\
(0.02)\end{array}$ & $\begin{array}{l}-0.032 \\
(0.016) * *\end{array}$ & $\begin{array}{c}-0.027 \\
(0.018)\end{array}$ & $\begin{array}{l}-0.037 \\
(0.017)^{* *}\end{array}$ & 491 & 0.144 & 0.201 \\
\hline $\begin{array}{l}\text { Distance to main road } \\
\text { (in } \mathrm{km})\end{array}$ & $\begin{array}{r}9.127 \\
{[12.446]}\end{array}$ & $\begin{array}{c}2.328 \\
(2.793)\end{array}$ & $\begin{array}{c}-0.722 \\
(3.117)\end{array}$ & $\begin{array}{c}-3.665 \\
(2.413)\end{array}$ & $\begin{array}{c}-3.432 \\
(2.551)\end{array}$ & 613 & $0.055^{*}$ & 0.968 \\
\hline $\begin{array}{l}\text { School inaccessible } \\
\text { during winter }\end{array}$ & $\begin{array}{c}0.425 \\
{[0.497]}\end{array}$ & $\begin{array}{c}-0.011 \\
(0.092)\end{array}$ & $\begin{array}{c}-0.023 \\
(0.095)\end{array}$ & $\begin{array}{l}-0.11 \\
(0.081)\end{array}$ & $\begin{array}{l}-0.174 \\
(0.082) * *\end{array}$ & 587 & $0.012 * *$ & 0.27 \\
\hline School has electricity & $\begin{array}{c}0.188 \\
{[0.392]}\end{array}$ & $\begin{array}{l}0.131 \\
(0.068)^{*}\end{array}$ & $\begin{array}{c}-0.044 \\
(0.074)\end{array}$ & $\begin{array}{l}-0.102 \\
(0.06)^{*}\end{array}$ & $\begin{array}{c}0.045 \\
(0.066)\end{array}$ & 601 & 0.875 & $0.033 * *$ \\
\hline School has toilets & $\begin{array}{c}0.495 \\
{[0.502]}\end{array}$ & $\begin{array}{c}0.085 \\
(0.066)\end{array}$ & $\begin{array}{c}0.013 \\
(0.075)\end{array}$ & $\begin{array}{c}-0.036 \\
(0.058)\end{array}$ & $\begin{array}{c}-0.079 \\
(0.059)\end{array}$ & 611 & 0.141 & 0.549 \\
\hline $\begin{array}{l}\text { Distance to the post office } \\
\text { (in } \mathrm{km} \text { ) }\end{array}$ & $\begin{array}{c}24.765 \\
{[27.239]}\end{array}$ & $\begin{array}{c}-4.703 \\
(3.989)\end{array}$ & $\begin{array}{c}3.541 \\
(4.025)\end{array}$ & $\begin{array}{c}0.113 \\
(2.679)\end{array}$ & $\begin{array}{c}1.008 \\
(3.016)\end{array}$ & 611 & 0.608 & 0.424 \\
\hline Number of school units & 117 & 80 & 78 & 176 & 176 & 628 & & \\
\hline
\end{tabular}

Notes: Unit of observation: School unit. Column 1: standard deviations presented in brackets. Columns 2-5: coefficients and standard errors (in parentheses) from an OLS regression of the school characteristic on treatment dummies, controlling for strata dummies. Standard errors are clustered at the school-sector level.

${ }^{\mathrm{a}}$ Conditional on teacher presence.

*** Significant at the 1 percent level.

** Significant at the 5 percent level.

* Significant at the 10 percent level.

Source: Preliminary school survey and baseline school survey

(including transfers conditional on health seeking behavior) was $\$ 43,7$ which corresponds to 20 percent of household consumption. ${ }^{8}$

Another way to gauge the relative size of the cash transfer is to compare it to the opportunity cost of being in school, in particular, the wage children can earn. In our context, the Tayssir cash allowance for children old enough for grades 5-6 represents a third of the median child labor earnings (a fifth of the mean) - though our estimates of child labor earnings are based on very few children in the labor force,

\footnotetext{
${ }^{7}$ Transfer reported in Coady (2000) for 1997-2000 period, expressed in 2008 USD.

${ }^{8}$ Fizbein et al. (2009).
} 
as less than 4 percent of out-of-school children and 2 percent of all children in our sample report any work outside the home. ${ }^{9}$

Parents had to formally enroll each of their children into the program. Headmasters, who had been trained through group-specific province-level meetings just before the start of the academic year, were responsible for disseminating information to parents of school-age children about the program and its rules, and for enrolling them. For all groups, this enrollment took place at the primary school, and required the presence of the designated beneficiary (the father or the mother, depending on which experimental group the school sector was in). In both years, the open enrollment period started at the beginning of the school year (early September) and lasted for approximately three months. Children who had been enrolled into the program in year 1 were automatically re-enrolled in year 2 provided the school headmaster forwarded their names to the provincial authorities.

In the LCT groups, the transfer was fixed and not conditional on attendance or continued enrollment, but parents still had to enroll their child in the Tayssir program yearly in order to receive the money. While in the original design enrolling in school at the beginning of the year was not a condition for enrolling in Tayssir, in practice the two turned out to be linked: enrollment in the Tayssir program was done at school by the headmaster and, de facto, children were systematically registered and enrolled in a grade by the headmaster at the same time they were registered for Tayssir (if not yet enrolled). (School registration is free in rural areas of Morocco.) The fact that Tayssir enrollment took place at the school, even when continued school enrollment was not required to receive the transfers, is an important feature, because drawing applicants into that environment served to link the program to education. Indeed, it made it very clear and salient to households that the transfers were coming from and overseen by the Ministry of Education, and were part of an effort to promote education. The flyers that schools were given to advertise the program showed schoolchildren sitting at their school desk and had the headline "Pilot program to fight against school dropout" and the phrase "So that your child's seat is not left empty" (see Appendix Figure A2). This is why we call this a Labeled Cash Transfer (LCT).

In the CCT groups, the transfer was formally conditional on enrollment and regular attendance. The rule was that the allowance for a given month and a given child would be cancelled if the child missed school more than four times over that month. Absences from school caused by the teacher's absence were excluded from this count. Headmasters, teachers, and school committees received guidelines from the Ministry of Education on how to monitor and record attendance and how to submit reports every two months to the provincial-level program manager at the Ministry. The reports included, for each month, the total number of absences for each child enrolled in the program. These reports were then digitized by the provincial-level program managers, and shared, through an integrated information system, with the

\footnotetext{
${ }^{9}$ In Ecuador, where child labor is more prevalent (at 14 percent of children aged 11-16 at baseline), Edmonds and Schady (2012) study cash transfers equivalent to 7 percent of monthly expenditures (compared to 5 percent in our case) but less than 20 percent of median child labor earnings (compared to 33 percent here). They find a large drop in children's involvement in paid employment.
} 
central management team at the Ministry of Education. The central management team determined whether the conditionality had been respected and estimated the amounts that each household should receive for any given month. This process was time consuming and created important delays, especially early on, as described below.

Headmasters were instructed to enroll only mothers or only fathers, depending on which variant of the program the school was in. There was, however, an exception policy: households with a written authorization from the Moqadem (the local representative of the Moroccan administration) could enroll another adult in the household. Exceptions were typically granted when the sampled recipient did not live at home (for example, if the father worked in the city and came home only a few times a year, the mother was allowed to enroll instead). Overall, as we discuss below, compliance with the gender assignment was above 80 percent.

The cash transfers were disbursed to the assigned recipients (upon presentation of a national ID card) at the local post office. Areas that did not have a post office (about a third of the sample) received the visit of a "mobile cashier" in charge of distributing the transfers. On average, the cost of a round trip to the nearest pick-up point was around $20 \mathrm{MAD}$ or 8 percent of the average transfer. However, if they wanted to save on transportation costs, recipients could wait and withdraw all their transfers at once.

Overall, program take-up was very high: 97 percent of households in our household sample had at least one child enrolled in Tayssir by the end of year 2, and the take-up rate at the household level was almost identical across all four treatment groups. Households had on average two children enrolled in the program. This is much higher than the take-up of a CCT program in Indonesia, for which poor households had to register by showing up on a specific registration day: Alatas et al. (2012b) find that only 61 percent of the very poorest households (those guaranteed eligibility) signed up (and the sign-up rate is lower among all income groups). The take-up rate in our household sample may be an overestimate of the overall take-up rate, however, since our household sample excludes households with no prior contact with the local school (given our sampling strategy, discussed in Section II.B). Our household sample also over-represents households living relatively close to the school. To the extent that headmasters played an important role in contacting households they knew or who lived nearby, take-up in our sample is an upper bound of overall take-up. Contrasting the administrative records on Tayssir enrollment at the municipality level with the (very noisy) data on total number of households in a given municipality as reported by the local chief (the Moqadem) confirms the take-up rate was quite high, however, with the ratio between the two at 88 percent on average (with a very large standard deviation, however).

Three payments were made to enrolled households over the course of the first year. Due to delays in setting up the system for collecting and managing school attendance data, the Ministry of Education decided in December 2008 that the first transfer, corresponding to the first two months (September-October 2008), would be given to all households enrolled in the program without conditionality. For the conditional groups, the next two transfers in year 1 were conditional on attendance. ${ }^{10}$

\footnotetext{
${ }^{10}$ See Figure A3 for the timeline of the program implementation. The first transfer took place in late January and early February, 2009. The second transfer took place in late May/early June 2009, and it covered four months,
} 
In year 2, five transfers were made to households, and each transfer covered a twomonth period, as per the program protocol. For the conditional groups, all those payments were conditional on attendance. To maintain comparability, each payment was made simultaneously to conditional and unconditional groups. Across groups, households qualified for just around 3,000 MAD ( \$390 in 2008 USD) on average in total transfers through the first 18 months of the pilot.

\section{Data}

To estimate the impacts of the Tayssir Program, we collected detailed data on schooling achievement in two school units (the main school unit and one randomly chosen satellite unit) for each of the 318 sectors included in the study.

Four types of data were collected. (i) We measured school participation through school visits spread over the two years of the program, for all students enrolled in the study schools at the beginning of "year 0" (the academic year 2007-2008). We call this the "school sample," and it comprises over 47,000 students. (ii) We conducted a comprehensive survey at both baseline and endline with close to 4,400 households - we call this the "household sample." (iii) We administered a basic arithmetic test (ASER test) to one child per household during the endline household survey. (iv) Finally, we conducted "awareness" surveys at and around schools to measure teachers' and households' understanding of the program. Figure A3 summarizes the timeline of the data collection and we provide below the details for each of these datasets.

\section{A. School Participation}

Through school visits, the research team (which had no relationship with the Tayssir team or the Ministry of Education and was blind to the assignment to the different groups) collected data on school participation. We conducted a total of seven visits per school. The first visit was announced, and conducted at baseline, in June 2008, just before the end of the preprogram school year (we call this "year 0"). During that first visit, we copied school registers for all grades 1 to 5. This register data provides the universe of children that were enrolled in school at the beginning of year 0 , and whether they had dropped out or were still enrolled by the end of year 0 (June 2008, when we conducted our baseline). This constitutes our "school sample." Appendix Table A1 provides summary statistics at the child level for this school sample, broken down by treatment group. The second visit was also announced, and conducted at the beginning of the first program year. Two additional (unannounced) visits were conducted during the first year of the program (in March/April and May 2009). The fifth visit was announced, and conducted at the beginning of the second academic year. Two unannounced visits were conducted later on that year (in February and April 2010).

November 2008 to February 2009. The third and last payment for year 1 covered the rest of the school year, and took place late August 2009/early September 2009. 
During each visit, we updated the schooling status of all children in the initial lists, recording who had dropped out of school and when, which grade each pupil was in (if still attending regularly), whether the teacher was present in class, and whether the pupil was present. Names of newly enrolled students were also recorded. To analyze the impact of the program on school participation and dropout, we use data from all seven visits. However, to analyze the impact of the program on attendance, we use only data from the four surprise visits.

Attrition in this dataset (shown in Appendix Table A1) is very low since we did not need to individually track each child in the sample to obtain their schooling status, but instead relied on whether the child was found in the classroom on the day of the visit, and if not, checked registers and interviewed teachers and other students/siblings to determine whether the child had dropped out. We consider a student as a dropout if he or she was absent from school on the surprise visit, and was considered as dropped out by the teachers and other students. We consider a student as attending school if he was present on the visit day, or absent but listed on the register as enrolled for that month and having attended school at least some time in the previous 30 days. ${ }^{11}$

\section{B. Household Surveys}

For each school unit, eight households were sampled for a baseline survey (administered in June 2008, before Tayssir was announced and before school sectors had been randomly assigned to either treatment or control) and an endline survey (administered in June 2010). The sampling frame used to select these households was the following. Enumerators visited each school (again, these were two per school sector, the main unit, and one satellite unit) in spring 2008 , and used the 2007/2008 school register, as well as the registers of the previous three academic years, to draw two lists: (i) the list of all households in the school's vicinity that had at least one child enrolled in school, and (ii) the list of households with no child currently enrolled in school but at least one child of school-age who had enrolled at some point but dropped out within the previous three years. A total of six households were randomly selected from list 1 , and two households were randomly selected from list 2 . This sampling method means that our sampling frame does not include households who never enrolled any school-age children in school, but such households appear very rare. (We attempted to get lists of such households from the Moqadem, but they could rarely come up with any household fitting that description, which is why systematically enrolling a few such households in the study at each location was not possible.)

\footnotetext{
${ }^{11}$ School attendance registers were very well kept and updated. Teachers are supposed to update the list of enrolled students every month (when they have to write the names of all currently active students on a new page) and to record their presence on a daily basis. Teachers typically do not copy the name of students that they consider as dropouts when they move on to a new page (i.e., a new month). The fact that we find a very high attendance rate of 95 percent (objectively measured through surprise spot checks) for those officially enrolled (on the register for that visit's month), while at the same time observing a high dropout rate, confirms that teachers truthfully report the de facto dropouts as dropouts.
} 
Overall, a total of 5,032 households were sampled. Of them, 4,832 (96 percent) could be interviewed at baseline. Of those interviewed at baseline, 91 percent were interviewed at endline. An additional 111 households that were sampled but not surveyed at baseline were found and surveyed at endline. Table A2 presents analyses of attrition at both baseline and endline. Attrition was more pronounced in the control group than Tayssir groups. To check whether this differential attrition yields imbalance in household characteristics, Table 2 presents summary statistics by group for the final, postattrition endline sample of 4,385 households. The groups appear relatively well balanced with respect to observable characteristics. Fewer than 10 percent of all possible pair-wise comparisons yield differences that are significant at the 10 percent level. There appears to be some differences in baseline schooling rates, however. In the control group, 7 percent of children 6-15 had never enrolled and 14 percent had enrolled but dropped out, with the remainder (79 percent) enrolled. The share out of school at baseline for the LCT-to-fathers group is significantly lower, with 3.2 percentage points fewer never-enrolled and 2.7 percentage points fewer dropouts. Schooling rates for the other treatment groups fall somewhere in between the control and the LCT-to-fathers group. In all analyses below we condition on baseline schooling status so these baseline differences do not drive our results.

Households in the sample are relatively large, with an average of 6.8 members across all groups, including 3.1 children under 16 years old and 2.4 children in the 6-15 age group, the target group for Tayssir. Literacy rates are quite low, with only 23 percent of household heads knowing how to read and write. Financial access is also very low, with only 3 percent of households holding a bank account.

\section{ASER Arithmetic Tests}

As part of the endline survey administered to study households, one child between 6 and 12 years old at baseline was randomly selected to take a short arithmetic test based on the ASER test developed by Pratham. ${ }^{12}$ This test does not evaluate children for age- or-grade specific competency. Instead, it tests the ability of children to perform basic arithmetic, such as recognizing a one-digit or two-digit number, performing a subtraction, and performing a division. Of the 4,682 children sampled, only about 3,316 (71 percent) were available for the arithmetic test during the endline survey. Panel B of Table A2 presents analysis of attrition, which was equally high across all five groups. Observable household characteristics for children who took the test are overall balanced (Table A3).

\section{Program Awareness Surveys}

In order to estimate how much communities knew about Tayssir and its rules by the end of the first program year, a survey on "program awareness" was conducted in 387 schools in April 2009. The survey included only a few questions such as: "Have

\footnotetext{
${ }^{12}$ See information on ASER at http://www.pratham.org/M-19-3-ASER.aspx.
} 
Table 2-Study Households: Balance Check

\begin{tabular}{|c|c|c|c|c|c|c|c|c|}
\hline & \multirow{2}{*}{$\begin{array}{l}\text { Mean in } \\
\text { control } \\
\text { group } \\
(1)\end{array}$} & \multirow{2}{*}{$\begin{array}{l}\text { Difference } \\
\text { between } \\
\text { LCT to } \\
\text { fathers } \\
\text { and } \\
\text { control } \\
(2)\end{array}$} & \multicolumn{3}{|c|}{$\begin{array}{l}\text { Difference between }[\ldots] \text { and } \\
\text { LCT to fathers }\end{array}$} & \multirow[b]{2}{*}{$\begin{array}{l}\text { Obs. } \\
(6)\end{array}$} & \multirow{2}{*}{$\begin{array}{l}p \text {-value } \\
\text { for CCT } \\
\text { different } \\
\text { from } \\
\text { LCT } \\
(7)\end{array}$} & \multirow{2}{*}{$\begin{array}{l}p \text {-value for } \\
\text { mother } \\
\text { different } \\
\text { from father } \\
\text { (8) }\end{array}$} \\
\hline & & & $\begin{array}{l}\text { LCT to } \\
\text { mothers } \\
\text { (3) }\end{array}$ & $\begin{array}{l}\text { CCTs to } \\
\text { fathers } \\
(4)\end{array}$ & $\begin{array}{l}\text { CCTs to } \\
\text { mothers } \\
(5)\end{array}$ & & & \\
\hline $\begin{array}{l}\text { Head of household } \\
\text { is male }\end{array}$ & $\begin{array}{c}0.97 \\
{[0.17]}\end{array}$ & $\begin{array}{c}0.009 \\
(0.011)\end{array}$ & $\begin{array}{r}-0.001 \\
(0.01)\end{array}$ & $\begin{array}{c}-0.001 \\
(0.009)\end{array}$ & $\begin{array}{r}-0.007 \\
(0.009)\end{array}$ & 4,385 & 0.539 & 0.39 \\
\hline $\begin{array}{l}\text { Age of head of } \\
\text { household }\end{array}$ & $\begin{array}{l}46.171 \\
{[9.751]}\end{array}$ & $\begin{array}{l}-1.259 \\
(0.614)^{* *}\end{array}$ & $\begin{array}{c}1.324 \\
(0.65)^{* *}\end{array}$ & $\begin{array}{l}1.369 \\
(0.531) * *\end{array}$ & $\begin{array}{c}0.562 \\
(0.522)\end{array}$ & 4,309 & 0.4 & 0.69 \\
\hline $\begin{array}{l}\text { Number of household } \\
\text { members }\end{array}$ & $\begin{array}{c}6.764 \\
{[2.057]}\end{array}$ & $\begin{array}{c}-0.021 \\
(0.142)\end{array}$ & $\begin{array}{c}0.006 \\
(0.157)\end{array}$ & $\begin{array}{l}-0.02 \\
(0.134)\end{array}$ & $\begin{array}{c}0.021 \\
(0.135)\end{array}$ & 4,385 & 0.971 & 0.712 \\
\hline $\begin{array}{l}\text { Number of children } \\
\quad 6-15\end{array}$ & $\begin{array}{c}2.394 \\
{[0.98]}\end{array}$ & $\begin{array}{l}-0.05 \\
(0.071)\end{array}$ & $\begin{array}{r}-0.025 \\
(0.074)\end{array}$ & $\begin{array}{c}0.033 \\
(0.069)\end{array}$ & $\begin{array}{l}-0.001 \\
(0.07)\end{array}$ & 4,385 & 0.497 & 0.445 \\
\hline $\begin{array}{l}\text { Percent of children } \\
6-15 \text { never } \\
\text { enrolled in school } \\
\text { at baseline } \\
\text { (year } 0 \text { ) }\end{array}$ & $\begin{array}{l}0.07 \\
{[0.163]}\end{array}$ & $\begin{array}{l}-0.032 \\
(0.011) * * *\end{array}$ & $\begin{array}{c}0.018 \\
(0.011)\end{array}$ & $\begin{array}{l}0.021 \\
(0.01)^{* *}\end{array}$ & $\begin{array}{c}0.008 \\
(0.009)\end{array}$ & 4,369 & 0.394 & 0.597 \\
\hline $\begin{array}{l}\text { Percent of children } \\
6-15 \text { who were } \\
\text { dropped out at } \\
\text { baseline (year } 0)\end{array}$ & $\begin{array}{c}0.141 \\
{[0.239]}\end{array}$ & $\begin{array}{l}-0.027 \\
(0.016) *\end{array}$ & $\begin{array}{c}0.009 \\
(0.017)\end{array}$ & $\begin{array}{l}0.03 \\
(0.015) * *\end{array}$ & $\begin{array}{l}0 \\
(0.014)\end{array}$ & 4,369 & 0.261 & $0.073 *$ \\
\hline $\begin{array}{l}\text { Household head } \\
\text { reads and writes }\end{array}$ & $\begin{array}{c}0.234 \\
{[0.424]}\end{array}$ & $\begin{array}{c}0.035 \\
(0.03)\end{array}$ & $\begin{array}{l}-0.067 \\
(0.031) * *\end{array}$ & $\begin{array}{c}-0.002 \\
(0.027)\end{array}$ & $\begin{array}{r}-0.032 \\
(0.027)\end{array}$ & 4,318 & 0.364 & $0.025^{* *}$ \\
\hline $\begin{array}{l}\text { Household head has } \\
\text { at least some } \\
\text { education }\end{array}$ & $\begin{array}{c}0.281 \\
{[0.45]}\end{array}$ & $\begin{array}{c}0.018 \\
(0.033)\end{array}$ & $\begin{array}{l}-0.05 \\
(0.032)\end{array}$ & $\begin{array}{c}0.015 \\
(0.027)\end{array}$ & $\begin{array}{c}-0.021 \\
(0.027)\end{array}$ & 4,303 & 0.25 & $0.026 * *$ \\
\hline $\begin{array}{l}\text { Monthly per capita } \\
\text { consumption } \\
\text { (MAD) }\end{array}$ & $\begin{array}{l}448.979 \\
{[196.751]}\end{array}$ & $\begin{array}{c}7.726 \\
(18.202)\end{array}$ & $\begin{array}{c}-11.233 \\
(20.95)\end{array}$ & $\begin{array}{l}-6.962 \\
(15.938)\end{array}$ & $\begin{array}{l}-4.625 \\
(17.177)\end{array}$ & 4,279 & 0.985 & 0.864 \\
\hline $\begin{array}{l}\text { Owns agricultural } \\
\text { land }\end{array}$ & $\begin{array}{c}0.636 \\
{[0.481]}\end{array}$ & $\begin{array}{c}0.004 \\
(0.043)\end{array}$ & $\begin{array}{c}0.024 \\
(0.045)\end{array}$ & $\begin{array}{c}0.023 \\
(0.038)\end{array}$ & $\begin{array}{c}-0.025 \\
(0.038)\end{array}$ & 4,277 & 0.63 & 0.283 \\
\hline Owns a cellphone & $\begin{array}{c}0.614 \\
{[0.487]}\end{array}$ & $\begin{array}{l}0.132 \\
(0.035) * * *\end{array}$ & $\begin{array}{c}-0.065 \\
(0.033) *\end{array}$ & $\begin{array}{l}-0.08 \\
(0.029) * * *\end{array}$ & $\begin{array}{l}-0.081 \\
(0.027)^{* * *}\end{array}$ & 4,348 & $0.021 * *$ & 0.325 \\
\hline Owns a television & $\begin{array}{c}0.714 \\
{[0.452]}\end{array}$ & $\begin{array}{c}0.041 \\
(0.048)\end{array}$ & $\begin{array}{c}-0.046 \\
(0.045)\end{array}$ & $\begin{array}{c}-0.059 \\
(0.038)\end{array}$ & $\begin{array}{c}-0.027 \\
(0.038)\end{array}$ & 4,348 & 0.417 & 0.725 \\
\hline Owns a bank account & $\begin{array}{c}0.03 \\
{[0.17]}\end{array}$ & $\begin{array}{c}0.012 \\
(0.015)\end{array}$ & $\begin{array}{c}0.001 \\
(0.016)\end{array}$ & $\begin{array}{c}-0.006 \\
(0.014)\end{array}$ & $\begin{array}{c}-0.007 \\
(0.015)\end{array}$ & 4,347 & 0.447 & 0.991 \\
\hline $\begin{array}{l}\text { Household has } \\
\text { electricity }\end{array}$ & $\begin{array}{c}0.545 \\
{[0.498]}\end{array}$ & $\begin{array}{c}0.071 \\
(0.069)\end{array}$ & $\begin{array}{c}-0.037 \\
(0.067)\end{array}$ & $\begin{array}{c}-0.087 \\
(0.058)\end{array}$ & $\begin{array}{c}0.004 \\
(0.058)\end{array}$ & 4,385 & 0.551 & 0.175 \\
\hline $\begin{array}{l}\text { Number of } \\
\text { households }\end{array}$ & 790 & 567 & 574 & 1,227 & 1,227 & 4,385 & & \\
\hline
\end{tabular}

Notes: Sample: random subset of around seven households per school unit, including only households also surveyed at endline (see Table A2 for attrition analysis). Sampling weights are used since households with dropout children were over-sampled. Unit of observation: Household. Column 1: standard deviations presented in brackets. Columns 2-5: coefficients and standard errors (in parentheses) from an OLS regression of the left-hand side variable on treatment dummies, controlling for strata dummies. Standard errors are clustered at the school-sector level.

*** Significant at the 1 percent level.

** Significant at the 5 percent level.

* Significant at the 10 percent level.

Source: Baseline household survey

you heard of a program called Tayssir?;" "Have you been receiving transfers from the government related to your children?;" "Do you know what the transfers depend on?;" etc. The survey was administered to teachers (for each school, we attempted to survey the headmaster or deputy headmaster, as well as one grade 4 Arabic language teacher) as well as parents (for each school, we attempted to survey two households 
from the household sample). A similar awareness survey was administered at the end of the second year (May/June 2010) to headmasters and teachers in all schools. We also included a module on Tayssir in the endline survey administered to study households.

\section{Empirical Strategy and Results}

\section{A. Empirical Strategy}

The random assignment of cash transfers, their conditionality, and their designated beneficiary across school sectors means that, in expectation, students in the control and various treatment groups have, conditional on baseline schooling status, comparable background characteristics and abilities. Thus, they likely would have, on average, comparable outcomes in the absence of any cash transfer program. By comparing outcomes between the LCT-to-fathers group and the control group, we can thus estimate the effect of the small labeled cash transfer program we are testing. By comparing outcomes across treatment groups, we can estimate the relative importance of the various program components-conditioning on attendance and beneficiary's gender. The sample size is large enough that we can detect, across subtreatment groups, differences in school participation rates as small as 1.5 percentage points in the household sample and 0.7 percentage point in the school sample.

We estimate the effect of being assigned to each of the treatment groups using the following specification:

$$
\begin{aligned}
Y_{i, j}=\alpha+\beta_{1} \times \text { TAYSSIR }_{j} & +\beta_{2} \times L C T_{\text {mother }_{j}}+\beta_{3} \times C C T_{\text {father }_{j}} \\
& +\beta_{4} \times C C T_{\text {mother }_{j}}+\mathbf{X}_{i, j}^{\prime} \gamma+\varepsilon_{i, j},
\end{aligned}
$$

where:

$Y_{i, j}$ is the outcome for student $i$ in school $j$;

TAYSSIR $_{j}$ is a dummy equal to 1 if school $j$ is selected for TAYSSIR in any form (i.e., in any of the cash transfer groups);

$L C T_{\text {mother }_{j}}$ is a dummy equal to 1 if school $j$ is in the LCT-to-mothers group;

$C C T_{\text {father }_{j}}$ is a dummy equal to 1 if school $j$ is in the CCT-to-fathers group;

$C C T_{\text {mother }_{j}}$ is a dummy equal to 1 if school $j$ is in the CCT-to-mothers group;

$\mathbf{X}_{i, j}$ is a vector of strata dummies, school-level controls (access to electricity and remoteness), and child-level controls (age, gender, schooling status, and grade at baseline). 
In this equation, $\widehat{\beta_{1}}$ estimates the effect of unconditional but labeled cash transfers paid to the father of primary school-age children, and therefore the impact of the version of the program that has minimal strings attached (since having the father pick up the money would be the natural default in Morocco). $\widehat{\beta_{2}}$ captures the differential (compared to LCT-to-fathers) effect of designating the mother as transfer recipient (while maintaining the lack of conditionality on attendance). $\widehat{\beta}_{3}$ estimates the differential effect of making transfers conditional on attendance (while keeping the father as transfer recipient) and, lastly, $\widehat{\beta_{4}}$ is the estimate of both making transfers conditional and paying them to the mother. Strata dummies take account of stratification variables used in the randomization. We adjust the standard errors for clustering at the school sector level. Finally, because our sampling procedure at the household level oversampled households with dropout children (our final household sample includes 17 percent of households with dropout children, while those households represent only 9 percent of the population), we use sampling weights in all analyses using the household survey data, so that our regressions are representative of the population from which we surveyed. Recall, however, that this population does not include children from households where no child had ever been enrolled in school, a group estimated to include just around 4.5 percent of the total children population. 13

In most tables we present estimates of equation (1) with the same format. Each row corresponds to a given dependent variable. Column 1 presents the mean of that variable in the control group (with its standard deviation in bracket underneath). Columns $2-5$ present the $\beta$ coefficient estimates and standard errors (in parentheses) from equation (1). Columns 7 and 8 present the $p$-values for the hypotheses that CCT has no differential impact compared to LCT and that transfers to fathers have no differential impacts compared to transfers to mothers. ${ }^{14}$ We only present results that include controls for the school and child characteristics mentioned above $\left(X_{i, j}\right)$, but results remain unchanged when we omit those controls, or if we add household-level controls (such as cell phone ownership and age of the household head, which are both somewhat imbalanced at baseline-results available upon request).

\section{B. Compliance with, and Understanding of, the Experimental Design}

To interpret the results, it is important to check that the experimental design was actually implemented as planned. Table 3 presents summary statistics on program implementation in the four Tayssir groups.

Enrollment in the Tayssir program was high. In the LCT-to-fathers group, 97 percent of the households in our survey had at least one child enrolled, and 73 percent

\footnotetext{
${ }^{13}$ This figure was computed as follows. Let's call $y$ the share of children age 6-11 in families who never enroll any child. Let's call $z$ the share of children who never enroll. We can write $z=y \times 1+(1-y) \times h$, where $h$ is the share of children who never enroll in families who enroll at least one child. In our (selected) household sample, 6.4 percent of children age 6-11 had never enrolled as of the end of academic year 2007/2008, so $h=0.064$. For that same year, the Ministry of Education estimates that 89.4 percent of rural children age 6-11 were enrolled in primary school, so this implies that $z$ is at most 0.106 From this we can back out that $y$ is at most $(0.106-0.064) /(1-0.064)=4.5$ percent.

${ }^{14}$ Note that the test in column 8 weights the impact of gender on CCTs three times as much as the impact of gender for LCTs, since in our experiment the CCT group was three times larger than the LCT group.
} 
Table 3-TaKe-Up and Compliance with Study Design

\begin{tabular}{|c|c|c|c|c|c|c|c|}
\hline & \multirow[b]{2}{*}{$\begin{array}{l}\text { Mean in } \\
\text { LCT to } \\
\text { fathers } \\
\text { (1) }\end{array}$} & \multicolumn{3}{|c|}{$\begin{array}{l}\text { Compared to LCT to fathers, } \\
\text { differential effect of ... }\end{array}$} & \multirow[b]{2}{*}{$\begin{array}{l}\text { Obs. } \\
(5)\end{array}$} & \multirow{2}{*}{$\begin{array}{l}p \text {-value for } \\
\text { CCT } \\
\text { different } \\
\text { from } \\
\text { LCT } \\
(6)\end{array}$} & \multirow{2}{*}{$\begin{array}{l}p \text {-value for } \\
\text { mother } \\
\text { different } \\
\text { from } \\
\text { father } \\
(7)\end{array}$} \\
\hline & & $\begin{array}{l}\text { LCT to } \\
\text { mothers } \\
(2)\end{array}$ & $\begin{array}{l}\text { CCTs to } \\
\text { fathers } \\
\text { (3) }\end{array}$ & $\begin{array}{l}\text { CCTs to } \\
\text { mothers } \\
(4)\end{array}$ & & & \\
\hline $\begin{array}{l}\text { Household enrolled in } \\
\text { program }\end{array}$ & $\begin{array}{c}0.967 \\
{[0.178]}\end{array}$ & $\begin{array}{c}0.011 \\
(0.012)\end{array}$ & $\begin{array}{c}0.003 \\
(0.01)\end{array}$ & $\begin{array}{c}0.006 \\
(0.011)\end{array}$ & 3,707 & 0.935 & 0.53 \\
\hline $\begin{array}{l}\text { Percent of children age 6-15 } \\
\text { enrolled in program }\end{array}$ & $\begin{array}{c}0.734 \\
{[0.268]}\end{array}$ & $\begin{array}{l}0.04 \\
(0.015)^{* * *}\end{array}$ & $\begin{array}{l}0.024 \\
(0.013)^{*}\end{array}$ & $\begin{array}{c}0.007 \\
(0.014)\end{array}$ & 3,707 & 0.662 & 0.97 \\
\hline $\begin{array}{l}\text { Female head is transfer } \\
\text { recipient }\end{array}$ & $\begin{array}{l}0.14 \\
{[0.347]}\end{array}$ & $\begin{array}{l}0.757 \\
(0.027) * * *\end{array}$ & $\begin{array}{c}-0.024 \\
(0.026)\end{array}$ & $\begin{array}{l}0.771 \\
(0.024) * * *\end{array}$ & 3,707 & 0.853 & $0 * * *$ \\
\hline $\begin{array}{l}\text { Mother usually goes alone to } \\
\text { pick up Tayssir transfer }\end{array}$ & $\begin{array}{l}0.06 \\
{[0.238]}\end{array}$ & $\begin{array}{l}0.319 \\
(0.03)^{* * *}\end{array}$ & $\begin{array}{c}0.023 \\
(0.023)\end{array}$ & $\begin{array}{l}0.28 \\
(0.031) * * *\end{array}$ & 3,690 & 0.749 & $0 * * *$ \\
\hline $\begin{array}{l}\text { Father usually goes alone to } \\
\text { pick up Tayssir transfer }\end{array}$ & $\begin{array}{c}0.712 \\
{[0.453]}\end{array}$ & $\begin{array}{l}-0.654 \\
(0.032)^{* * *}\end{array}$ & $\begin{array}{c}0.022 \\
(0.03)\end{array}$ & $\begin{array}{l}-0.682 \\
(0.028)^{* * *}\end{array}$ & 3,690 & 0.986 & $0 * * *$ \\
\hline $\begin{array}{l}\text { Mother and father usually go } \\
\text { together to pick up Tayssir } \\
\text { transfer }\end{array}$ & $\begin{array}{l}0.02 \\
{[0.139]}\end{array}$ & $\begin{array}{l}0.122 \\
(0.019) * * *\end{array}$ & $\begin{array}{c}-0.021 \\
(0.011) *\end{array}$ & $\begin{array}{l}0.116 \\
(0.017) * * *\end{array}$ & 3,690 & 0.297 & $0 * * *$ \\
\hline $\begin{array}{l}\text { Mother usually goes with } \\
\text { other people to pick up } \\
\text { Tayssir transfer }\end{array}$ & $\begin{array}{c}0.069 \\
{[0.253]}\end{array}$ & $\begin{array}{l}0.272 \\
(0.032) * * *\end{array}$ & $\begin{array}{c}-0.025 \\
(0.021)\end{array}$ & $\begin{array}{l}0.348 \\
(0.032) * * *\end{array}$ & 3,690 & 0.42 & $0 * * *$ \\
\hline $\begin{array}{l}\text { Cost of a round trip to the } \\
\text { nearest pick-up point } \\
\text { (MAD) }\end{array}$ & $\begin{array}{r}21.149 \\
{[25.42]}\end{array}$ & $\begin{array}{c}0.572 \\
(2.605)\end{array}$ & $\begin{array}{c}-0.998 \\
(2.109)\end{array}$ & $\begin{array}{c}1.821 \\
(2.222)\end{array}$ & 3,586 & 0.933 & 0.113 \\
\hline Number of payments received ${ }^{a}$ & $\begin{array}{c}6.562 \\
{[1.387]}\end{array}$ & $\begin{array}{c}-0.096 \\
(0.106)\end{array}$ & $\begin{array}{r}-0.044 \\
(0.081)\end{array}$ & $\begin{array}{c}-0.109 \\
(0.098)\end{array}$ & 3,477 & 0.695 & 0.311 \\
\hline $\begin{array}{l}\text { Amount for which the } \\
\text { household was eligible }^{\mathrm{a}}\end{array}$ & $\begin{array}{c}3,048.059 \\
{[1,486.965]}\end{array}$ & $\begin{array}{l}-147.29 \\
(111.585)\end{array}$ & $\begin{array}{l}-97.21 \\
(99.745)\end{array}$ & $\begin{array}{l}-256.075 \\
(103.864)^{* *}\end{array}$ & 3,470 & 0.123 & $0.011 * *$ \\
\hline $\begin{array}{l}\text { Sum of payments cashed out } \\
\text { as share of monthly } \\
\text { expenditures at baseline }\end{array}$ & $\begin{array}{c}1.118 \\
{[0.726]}\end{array}$ & $\begin{array}{c}0.008 \\
(0.067)\end{array}$ & $\begin{array}{c}-0.001 \\
(0.053)\end{array}$ & $\begin{array}{c}-0.075 \\
(0.055)\end{array}$ & 3,367 & 0.277 & 0.168 \\
\hline $\begin{array}{l}\text { Number of months (out of } \\
16 \text { total) in which at least } \\
\text { one child in the household } \\
\text { had more than } 4 \text { absences }\end{array}$ & & & 1.034 & 0.651 & & & 0.117 \\
\hline
\end{tabular}

Notes: Unit of observation: Household. Sampling weights are used since households with dropout children were over-sampled. Column 1: standard deviations presented in brackets. Columns 2-5: coefficients and standard errors (in parentheses) from an OLS regression of the left-hand side variable on treatment dummies, controlling for strata dummies, and variables specified below. Standard errors are clustered at the school-sector level. School-level controls: access to electricity and remoteness. Household-level controls: share of children enrolled in school at baseline.

*** Significant at the 1 percent level.

** Significant at the 5 percent level.

* Significant at the 10 percent level.

Source: Endline Household survey

${ }^{\mathrm{a}}$ Tayssir Administrative database

of the children ages 6-15 at baseline were enrolled. There is no systematic pattern by gender or by conditionality: at the child level, enrollment was a little higher in the LCT-to-mothers group and in the CCT-to-fathers group than in the other two. Compliance with the gender assignment was very high: it was close to 89 percent, on average, in schools where mothers had been designated as recipients, and around 80 percent in schools where fathers had been. This lower compliance rate for fathers is primarily due to the fact that men in rural Morocco sometimes out-migrate for work for part of the year. Overall, though, fathers were over 75 percent more likely to be Tayssir recipients in the father groups than in the mother groups; therefore 
our study is powered to detect impacts of the designated gender of the recipient on school participation as small as 1.7 percentage points in the household sample (0.9 percentage point in the school sample). ${ }^{15}$

Compliance by the Tayssir staff with the transfer rules was high as well. Administrative data show that, after the first transfer that all households got unconditionally, all subsequent transfers made to parents in the CCT groups were a function of attendance records, while none of the transfers in the LCT groups were. As a result, households in the LCT groups received more money over the lifetime of the program (though the difference is not very large, given that overall compliance with the conditionality was extremely high in the CCT groups).

Conditionality appears to have been poorly understood, however. In Table 4, we present data on understanding of the program in both years. While teachers were quite well informed on the exact amounts of the transfers for various age groups, even for them there is at most a 20 percentage point difference in the beliefs that transfers are conditional on attendance between teachers in the CCT and those in the LCT groups (panel A). While this difference is highly significant, it is quite far from the 100 percentage point difference we would have expected under perfect understanding. Over the course of the program, understanding improved among teachers. By the end of year 2, close to 75 percent of teachers in CCT schools believed transfers were conditional on attendance, against only 40 percent in LCT schools.

Our measure of understanding of parents is, unfortunately, not perfect (it is very difficult to ask parents neutral (nonleading) questions about their understanding of the rules, and be sure that they have actually understood the questions), but the data we have suggest that parents were confused. The question we asked at the end of year 1 was: "Can all children in this community receive the transfer, or only some?," and if the answer was "only some," we then asked: "what criteria do they need to fulfill to receive the transfer?" There was no apparent difference in beliefs about the conditionality between CCT and LCT groups at the end of year 1 (panel C), with just about 50 percent of parents in all groups thinking that the transfers were conditional on attendance (so parents may just have been taking a guess when answering the survey). At the end of year 2, we asked: "Is the amount that a child in a given grade receives fixed, or does it depend on some conditions?" And for those who said it depended on conditions, we then asked "What does the transfer amount depend on?" By the end of year 2, confusion had cleared in the LCT communities, with over 80 percent of parents reporting the transfers were fixed, thus not conditional. ${ }^{16}$ But the dominant belief in the CCT groups was also that transfer amounts were fixed

\footnotetext{
${ }^{15}$ One could be concerned that the money, while handed to the mothers, was directly appropriated by the father. To test this, Table 3 also checks whether the designated recipient picked up the cash transfer alone. We find that 33 percent of designated mothers picked up the transfer alone (compared to 70 percent of designated fathers). Fourteen percent of designated mothers were accompanied by their husband when they picked up the transfers, and 40 percent were accompanied by another household member. Given this, the lack of heterogeneity in program impacts across the gender recipient may not be very surprising, as women's role in financial transactions appears limited (although while men are typically making purchases, data from household surveys suggest that women are often involved in the decision of what purchases to make, especially when it comes to household and children expenditures)

${ }^{16}$ In the LCT group, program officers visited individual households at the end of year 1 to reiterate that they only needed to enroll their children in Tayssir at the school to get the transfer every month.
} 
TABLE 4-Program UNDERSTANDING

\begin{tabular}{|c|c|c|c|}
\hline & $\begin{array}{l}\text { Mean in } \\
\text { LCT groups } \\
\text { (1) }\end{array}$ & $\begin{array}{l}\text { Differential } \\
\text { effect of CCT } \\
\text { (2) }\end{array}$ & $\begin{array}{l}\text { Obs. } \\
(3)\end{array}$ \\
\hline $\begin{array}{l}\text { Panel A. Program understanding among teachers at the end of year } 1 \\
\text { Thinks the transfers are conditional on attendance }\end{array}$ & $\begin{array}{c}0.535 \\
{[0.501]}\end{array}$ & $\begin{array}{l}0.168 \\
(0.051)^{* * *}\end{array}$ & 457 \\
\hline $\begin{array}{l}\text { If thinks transfers are conditional: knows precise rule } \\
(<5 \text { absences })\end{array}$ & $\begin{array}{c}0.737 \\
{[0.443]}\end{array}$ & $\begin{array}{l}0.181 \\
(0.063)^{* * *}\end{array}$ & 292 \\
\hline Knows exact amount of transfer for compliant fourth-grade child & $\begin{array}{c}0.852 \\
{[0.356]}\end{array}$ & $\begin{array}{c}0.021 \\
(0.035)\end{array}$ & 457 \\
\hline Could not be surveyed & $\begin{array}{c}0.123 \\
{[0.33]}\end{array}$ & $\begin{array}{l}0.07 \\
(0.04) *\end{array}$ & 542 \\
\hline \multicolumn{4}{|l|}{ Panel B. Program understanding among teachers at the end of year 2} \\
\hline Thinks the transfers are conditional on attendance & $\begin{array}{c}0.399 \\
{[0.491]}\end{array}$ & $\begin{array}{l}0.37 \\
(0.046)^{* * *}\end{array}$ & 690 \\
\hline $\begin{array}{l}\text { If thinks transfers are conditional: knows precise rule } \\
(<5 \text { absences })\end{array}$ & $\begin{array}{c}0.747 \\
{[0.437]}\end{array}$ & $\begin{array}{l}0.095 \\
(0.056)^{*}\end{array}$ & 453 \\
\hline Knows exact amount of transfer for compliant fourth-grade child & $\begin{array}{c}0.877 \\
{[0.329]}\end{array}$ & $\begin{array}{c}0.023 \\
(0.027)\end{array}$ & 659 \\
\hline Could not be surveyed & $\begin{array}{c}0.084 \\
{[0.277]}\end{array}$ & $\begin{array}{c}0.026 \\
(0.019)\end{array}$ & 767 \\
\hline \multicolumn{4}{|l|}{ Panel C. Program understanding among parents at the end of year 1} \\
\hline Ever heard of the program & $\begin{array}{c}0.942 \\
{[0.234]}\end{array}$ & $\begin{array}{r}-0.036 \\
(0.029)\end{array}$ & 664 \\
\hline $\begin{array}{l}\text { Thinks the transfers are conditional on something but does not } \\
\text { know what }\end{array}$ & $\begin{array}{c}0.296 \\
{[0.458]}\end{array}$ & $\begin{array}{c}0.037 \\
(0.043)\end{array}$ & 620 \\
\hline Thinks the transfers are conditional on attendance & $\begin{array}{l}0.49 \\
{[0.501]}\end{array}$ & $\begin{array}{c}-0.011 \\
(0.051)\end{array}$ & 620 \\
\hline $\begin{array}{l}\text { If thinks transfers are conditional: knows precise rule } \\
(<5 \text { absences })\end{array}$ & $\begin{array}{c}0.313 \\
{[0.466]}\end{array}$ & $\begin{array}{c}0.104 \\
(0.07)\end{array}$ & 315 \\
\hline Could not be surveyed & $\begin{array}{c}0.068 \\
{[0.252]}\end{array}$ & $\begin{array}{c}-0.007 \\
(0.025)\end{array}$ & 702 \\
\hline \multicolumn{4}{|l|}{ Panel D. Program understanding among parents at the end of year 2} \\
\hline Ever heard of the program & $\begin{array}{c}0.995 \\
{[0.07]}\end{array}$ & $\begin{array}{l}-0.007 \\
(0.003) * *\end{array}$ & 3,707 \\
\hline Thinks the transfers are conditional on something but does not know what & $\begin{array}{c}0.068 \\
{[0.251]}\end{array}$ & $\begin{array}{l}0.016 \\
(0.009)^{*}\end{array}$ & 3,654 \\
\hline Thinks the transfers are conditional on attendance & $\begin{array}{c}0.115 \\
{[0.319]}\end{array}$ & $\begin{array}{c}0.031 \\
(0.017) *\end{array}$ & 3,654 \\
\hline $\begin{array}{l}\text { If thinks transfers are conditional: knows precise rule } \\
(<5 \text { absences })\end{array}$ & $\begin{array}{l}0.7 \\
{[0.46]}\end{array}$ & $\begin{array}{c}0.014 \\
(0.055)\end{array}$ & 481 \\
\hline Could not be surveyed & $\begin{array}{c}0.077 \\
{[0.267]}\end{array}$ & $\begin{array}{c}0.005 \\
(0.012)\end{array}$ & 3,932 \\
\hline
\end{tabular}

Notes: Weights are included in panel C to get a sample representative of households surveyed at baseline. Sampling weights are used in panel D since households with dropout children were over-sampled. Column 1: standard deviations presented in brackets. Column 2: coefficients and standard errors (in parentheses) from an OLS regression of the left-hand side variable on a Conditional Treatment dummy, controlling for strata dummies and variables specified below. Standard errors are clustered at the school-sector level. Panels A and B controls include: respondent gender, respondent status (teacher or headmaster), and school-level controls for access to electricity and remoteness. Panel C controls include: school-level controls for access to electricity and remoteness, and household level controls for share of children enrolled in school at baseline.

*** Significant at the 1 percent level.

** Significant at the 5 percent level.

* Significant at the 10 percent level.

Source: Panels A-C: Knowledge surveys administered to a subset of school teachers (including school directors) and households. Panel D: Endline survey administered to all households sampled for the study. 
and thus not conditional on attendance. This could be because, as we will see, school attendance happens to be very high in Morocco, conditional on enrollment. Most households in the CCT groups therefore ended up getting the full transfers, and had no experience of what would happen if the children were absent a lot. What's more, as shown in Figure A3, government delays meant that transfers arrived in lumps of different sizes (from two to four months worth) with a delay of at least three months - making it difficult for parents to infer the rules by themselves.

The relatively poor understanding of the CCT rules among intended beneficiaries is an important outcome itself. Indeed, at the beginning of each school year, an effort was made to make communities (who were the ones in charge of enrolling parents) understand the rules of the program. Each school director received instructions and handouts explaining the rules specific to their school sector. If, despite this, parents only have a dim sense of what the program rules are and the extent to which they're enforced, the role conditionality plays in providing incentives is necessarily blunted. This relates to a recent paper by Kaufmann, La Ferrara, and Brollo (2012): studying a CCT program in Brazil in which conditionality is strictly enforced, they find that child attendance increases once households get formal warnings that their child's absenteeism threatens their standing in the program, and increases even more after the households start being punished. This highlights the role of perceptions in the role that incentives can play in CCT. This is an important point since timely enforcement of conditionality, and therefore their proper understanding, is likely to be difficult to achieve in many settings. Evaluations of cash transfer programs so far have not systematically reported data on program comprehension, so comparing the level of understanding in our setting with that in others is difficult. In particular, Akresh, de Walque, and Kazianga (2013) do not report perceptions of conditionality by parents in their program. Baird, McIntosh, and Özler (2011) look at the perception of the conditionality among adolescent girls receiving a UCT by conducting a few qualitative interviews. They report a good understanding of the program rules (i.e., of the fact that no condition is required to receive the transfer), but they also provide evidence that girls in the UCT arm had friends in the CCT arm and knew the school attendance of these friends was monitored, putting the UCT in the broader context of an education program.

\section{Results: Impacts on School Participation}

Table 5 shows the main results on school participation. We present the results obtained from two separate sources: the household surveys (panel A) and the school visits (panel B), finding very consistent results across the two sources.

Starting with the household sample, the first row of the table shows the main result: the impact of the program on school participation at the end of year 2 among all primary school-aged children in the household sample, irrespective of status at baseline (but controlling for schooling status at baseline). School participation is a dummy equal to 1 if the child was reported as having attended school at least once in the last month of program year 2. The effect is very large. We find that school participation is 7.4 percentage points higher in the LCT-to-fathers group than in the control group. This corresponds to a decrease in nonparticipation of around 
TABle 5-EFfect on School Participation

\begin{tabular}{|c|c|c|c|c|c|c|c|c|}
\hline & \multirow{2}{*}{$\begin{array}{l}\text { Mean } \\
\text { in } \\
\text { control } \\
\text { group } \\
(1)\end{array}$} & \multirow{2}{*}{$\begin{array}{l}\text { Impact } \\
\text { of LCT } \\
\text { to } \\
\text { fathers } \\
\text { (2) }\end{array}$} & \multicolumn{3}{|c|}{$\begin{array}{c}\text { Difference between }[\ldots] \text { and } \\
\text { LCT to fathers }\end{array}$} & \multirow[b]{2}{*}{$\begin{array}{l}\text { Obs. } \\
(6)\end{array}$} & \multirow{2}{*}{$\begin{array}{l}p \text {-value } \\
\text { for } \\
\text { CCT } \\
\text { different } \\
\text { from } \\
\text { LCT } \\
(7)\end{array}$} & \multirow{2}{*}{$\begin{array}{l}p \text {-value } \\
\text { for mother } \\
\text { different } \\
\text { from father } \\
\quad(8)\end{array}$} \\
\hline & & & $\begin{array}{l}\text { LCT to } \\
\text { mothers } \\
(3)\end{array}$ & $\begin{array}{l}\text { CCTs to } \\
\text { fathers } \\
\text { (4) }\end{array}$ & $\begin{array}{l}\text { CCTs to } \\
\text { mothers } \\
(5)\end{array}$ & & & \\
\hline \multicolumn{9}{|l|}{ Panel A. Household sample } \\
\hline $\begin{array}{l}\text { Attending school by end of } \\
\text { year } 2 \text {, among those } 6-15 \\
\text { at baseline }\end{array}$ & $\begin{array}{c}0.737 \\
{[0.44]}\end{array}$ & $\begin{array}{l}0.074 \\
(0.016) * * *\end{array}$ & $\begin{array}{c}0.004 \\
(0.014)\end{array}$ & $\begin{array}{r}-0.019 \\
(0.012)\end{array}$ & $\begin{array}{c}-0.021 \\
(0.013)\end{array}$ & 11,074 & $0.01 * * *$ & 0.962 \\
\hline $\begin{array}{l}\text { Dropped out by end of } \\
\text { year } 2 \text {, among those } \\
\text { enrolled in grades } 1-4 \text { at } \\
\text { baseline }\end{array}$ & $\begin{array}{c}0.1 \\
{[0.3]}\end{array}$ & $\begin{array}{l}-0.076 \\
(0.012) * * *\end{array}$ & $\begin{array}{l}-0.005 \\
(0.008)\end{array}$ & $\begin{array}{l}0.014 \\
(0.007)^{* *}\end{array}$ & $\begin{array}{c}0.004 \\
(0.007)\end{array}$ & 5,998 & $0.012 * *$ & 0.122 \\
\hline $\begin{array}{l}\text { Attending school by end of } \\
\text { year } 2 \text { if had dropped out } \\
\text { at any time before } \\
\text { baseline }\end{array}$ & $\begin{array}{c}0.147 \\
{[0.355]}\end{array}$ & $\begin{array}{l}0.121 \\
(0.041) * * *\end{array}$ & $\begin{array}{c}0.005 \\
(0.048)\end{array}$ & $\begin{array}{r}-0.058 \\
(0.041)\end{array}$ & $\begin{array}{r}-0.044 \\
(0.04)\end{array}$ & 1,264 & $0.061 *$ & 0.553 \\
\hline $\begin{array}{l}\text { Never enrolled in school by } \\
\text { end of year } 2 \text {, among those } \\
6-15 \text { in year } 0\end{array}$ & $\begin{array}{c}0.035 \\
{[0.185]}\end{array}$ & $\begin{array}{c}-0.011 \\
(0.008)\end{array}$ & $\begin{array}{c}0.003 \\
(0.006)\end{array}$ & $\begin{array}{l}0.012 \\
(0.006) * *\end{array}$ & $\begin{array}{c}0.001 \\
(0.005)\end{array}$ & 11,072 & 0.205 & $0.091 *$ \\
\hline \multicolumn{9}{|l|}{ Panel B. School sample } \\
\hline $\begin{array}{l}\text { Dropped out by end of } \\
\text { year } 2 \text {, among those } \\
\text { enrolled in grades } 1-4 \text { at } \\
\text { baseline }\end{array}$ & $\begin{array}{c}0.076 \\
{[0.265]}\end{array}$ & $\begin{array}{l}-0.051 \\
(0.01)^{* * *}\end{array}$ & $\begin{array}{c}0.006 \\
(0.006)\end{array}$ & $\begin{array}{c}0.004 \\
(0.005)\end{array}$ & $\begin{array}{c}-0.002 \\
(0.005)\end{array}$ & 35,755 & 0.54 & 0.497 \\
\hline $\begin{array}{l}\text { Dropped out during year 1, } \\
\text { among those enrolled in } \\
\text { grades } 1-4 \text { at baseline }\end{array}$ & $\begin{array}{c}0.029 \\
{[0.168]}\end{array}$ & $\begin{array}{l}-0.017 \\
(0.007)^{* *}\end{array}$ & $\begin{array}{c}0.001 \\
(0.004)\end{array}$ & $\begin{array}{c}0.000 \\
(0.003)\end{array}$ & $\begin{array}{r}-0.004 \\
(0.003)\end{array}$ & 35,755 & 0.339 & 0.277 \\
\hline $\begin{array}{l}\text { Dropped out during year } 2 \text {, } \\
\text { among those enrolled in } \\
\text { grades } 1-4 \text { at baseline }^{\mathrm{a}}\end{array}$ & $\begin{array}{c}0.048 \\
{[0.214]}\end{array}$ & $\begin{array}{l}-0.036 \\
(0.005) * * *\end{array}$ & $\begin{array}{c}0.005 \\
(0.004)\end{array}$ & $\begin{array}{c}0.004 \\
(0.003)\end{array}$ & $\begin{array}{c}0.002 \\
(0.003)\end{array}$ & 35,215 & 0.976 & 0.904 \\
\hline $\begin{array}{l}\text { Attendance rate during } \\
\text { surprise school visits, } \\
\text { among those enrolled }\end{array}$ & $\begin{array}{l}0.955 \\
{[0.206]}\end{array}$ & $\begin{array}{r}0.007 \\
(0.01)\end{array}$ & $\begin{array}{c}0.002 \\
(0.009)\end{array}$ & $\begin{array}{c}0.007 \\
(0.007)\end{array}$ & $\begin{array}{c}0.007 \\
(0.007)\end{array}$ & 86,694 & 0.125 & 0.918 \\
\hline $\begin{array}{l}\text { Completed primary school, } \\
\text { among those enrolled in } \\
\text { grade } 5 \text { at baseline }\end{array}$ & $\begin{array}{c}0.644 \\
{[0.479]}\end{array}$ & $\begin{array}{l}0.079 \\
(0.032)^{* *}\end{array}$ & $\begin{array}{c}-0.029 \\
(0.036)\end{array}$ & $\begin{array}{c}-0.025 \\
(0.035)\end{array}$ & $\begin{array}{c}-0.041 \\
(0.031)\end{array}$ & 6,680 & 0.408 & 0.46 \\
\hline
\end{tabular}

Notes: Each row presents the results of a separate regression. Column 1: standard deviations presented in brackets. Columns 2-5: coefficients and standard errors (in parentheses) from an OLS/LPM regression of the left-hand side variable on treatment dummies, controlling for strata dummies and variables specified below. Standard errors are clustered at the school-sector level. Panel A: school-level controls include: access to electricity and remoteness. Household controls include: share of children enrolled in school at baseline and household owns a cellphone. Individual controls include: age, gender, and schooling status at baseline (end of year 0). Panel B: individual controls include: age, gender, schooling status, and grade the child attended at the end of year 0; school-level controls include access to electricity and remoteness. The regression on attendance also controls for the day of the visit.

${ }^{\text {a }}$ Dropout during year $X$ include dropouts in the summer between school year $X-1$ and year $X$, as well as dropouts in the course of year $X$.

*** Significant at the 1 percent level.

** Significant at the 5 percent level.

* Significant at the 10 percent level.

Source: Panel A: Household survey collected from study households; unit of observation: child; average of 2.5 children per household; sampling weights are used since households with dropout children were over-sampled. Panel B: school visits data; unit of observation: child (rows 1, 2, 3, 5 of panel B) and child-day (row 4 of panel B). 
30 percent. It is much larger than the impact of the first CCT, PROGRESA, at the primary level, however, primary school participation rates are much lower to start with in Morocco than in Mexico. The effect is similar regardless of the gender of the recipient (father/mother) but 2 percentage points higher (significantly so) under the LCT than under the CCT program.

The next rows provide a breakdown of the school participation effect by baseline school participation status. We find that both the dropout and the re-enrollment margins are affected. In the household sample, the dropout rate diminishes by 76 percent under the Tayssir program, no matter how it is implemented (a drop of 7.6 percentage points, off of a base rate of 10 percent in the control group). In the much larger school sample (panel B), the results are very similar: dropout declines from 7.6 percent in the control group to about 2.5 percent in all the Tayssir groups. The consistency between the self-reported participation data in the household survey and the school sample results (which are based on direct observations in classrooms during spot checks) is important and implies that parental reports of child participation were truthful.

The household data also show that re-entry almost doubles in the LCT groups (from 14.7 percent in the control group to 26.8 percent in the LCT-to-fathers group). In the CCT group, the effect is still large, but significantly smaller. The re-entry difference is the source of the greater overall impact on school participation of the LCT compared to the CCT.

Since CCT is conditional on attendance, while LCT is not, it is important to check the impact on attendance. The results of surprise attendance checks are presented in row 4 of panel B (for the school sample). Note that attendance conditional on enrollment is a selected outcome, since the program affects dropout, and this would bias us against finding positive impact on attendance. Attendance of enrolled children is very high overall during the periods covered by our unannounced spot checks (February, March, and May). The mean attendance rate of 95.5 percent in the control group corresponds to an average of 1.1 days of absence per month, well below the threshold of 4 absences imposed on students in the CCT arm. Attendance in the LCT group is, if anything, higher than in the control group, though not significantly so. The LCT impact on school participation that we found in the household survey data thus translates into effective participation in school, and it is definitely not the case that parents enrolled their children in school just to get enrolled with Tayssir and did not bother to send them to school very regularly afterwards.

If children spent more time in school, what did school participation crowd out? We collected hour-level time-use data for the day preceding the endline survey for every child aged 6-15 at baseline. Table 6 presents results from this data, restricting the sample to the 25 percent of households interviewed before the summer school break started. (We don't present the four versions of the Tayssir program separately, as the sample size is too small to detect small differences between them, but we find no systematic patterns.) Looking first on the extensive margin of school participation, we find a large impact of the Tayssir transfers, with children of program households about 60 percent more likely to have attended school the day before the survey. This is a much larger effect than that observed in Table 5, and suggests that the program has much more bite in the very last weeks of school before the summer 
TABLE 6-Daily Time UsE

\begin{tabular}{|c|c|c|c|}
\hline & $\begin{array}{l}\text { Mean in } \\
\text { control group } \\
\text { (1) }\end{array}$ & $\begin{array}{c}\text { Effect of Tayssir } \\
\text { (any type of treatment group) } \\
(2)\end{array}$ & $\begin{array}{l}\text { Obs. } \\
(3)\end{array}$ \\
\hline Spent at least some time in school & $\begin{array}{c}0.36 \\
{[0.48]}\end{array}$ & $\begin{array}{l}0.21 \\
(0.04) * * *\end{array}$ & 1,227 \\
\hline \multicolumn{4}{|c|}{ Dependent variable: Minutes spent doing [ ... ] during the day before survey, children 6-15 at baseline } \\
\hline Any type of schooling activity & $\begin{array}{l}140.94 \\
{[178]}\end{array}$ & $\begin{array}{l}90.48 \\
(16.6)^{* * *}\end{array}$ & 1,227 \\
\hline \multicolumn{4}{|l|}{ Including: } \\
\hline Time spent in school & $\begin{array}{c}90.83 \\
{[126.71]}\end{array}$ & $\begin{array}{l}56.5 \\
(11.69) * * *\end{array}$ & 1,227 \\
\hline Time spent doing homework & $\begin{array}{c}31.25 \\
{[66.76]}\end{array}$ & $\begin{array}{l}16.14 \\
(7.64) * *\end{array}$ & 1,227 \\
\hline Time to go and to come back from school & $\begin{array}{c}18.75 \\
{[32.59]}\end{array}$ & $\begin{array}{l}18.07 \\
(3.82) * * *\end{array}$ & 1,227 \\
\hline Household chores & $\begin{array}{c}97.19 \\
{[148.67]}\end{array}$ & $\begin{array}{r}-13.37 \\
(8.99)\end{array}$ & 1,227 \\
\hline Working on household business/farm/outside & $\begin{array}{c}69.45 \\
{[149.83]}\end{array}$ & $\begin{array}{l}-31.77 \\
(12.95) * *\end{array}$ & 1,227 \\
\hline Social activities/leisure ${ }^{\mathrm{a}}$ & $\begin{array}{c}307.69 \\
{[190.26]}\end{array}$ & $\begin{array}{l}-55.54 \\
(16.43) * * *\end{array}$ & 1,227 \\
\hline Personal time (eating, sleeping, dressing ... ) & $\begin{array}{l}749.96 \\
{[96.04]}\end{array}$ & $\begin{array}{c}9.14 \\
(8.09)\end{array}$ & 1,227 \\
\hline $\begin{array}{l}\text { Other activities (not doing anything, walking } \\
\text { (not to school) ... }\end{array}$ & $\begin{array}{l}58 \\
{[81.72]}\end{array}$ & $\begin{array}{r}-5.96 \\
(8.41)\end{array}$ & 1,227 \\
\hline
\end{tabular}

Notes: Unit of observation: child. Sample is restricted to 554 households interviewed before the summer school break started (June 15, 2010). Column 1: standard deviations presented in brackets. Column 2: coefficients and standard errors (in parentheses) from an OLS regression of the left-hand side variable on a Tayssir dummy, controlling for strata dummies and variables specified below. Standard errors are clustered at the school-sector level. Child controls include: age, gender, schooling status, and grade in year 0 (if any) and day of the week the survey was administered. All regressions also include household- and school-level controls as in panel A of Table 5. Sampling weights are used since households with dropout children were over-sampled.

${ }^{\mathrm{a}}$ This category consists of seven sub-activities prespecified in the survey under the header "leisure/social activities:" social and religious activities, social celebrations, playing with other children, visiting family or neighbors, playing sports, watching TV, using the internet or playing video games, and playing at home.

*** Significant at the 1 percent level.

** Significant at the 5 percent level.

* Significant at the 10 percent level.

Source: Endline household survey

break—a period during which both pupils and teacher attendance appears much spottier than the rest of the year.

Correspondingly, we see a large increase in the time children spent in school-related activities in the day before the survey (this includes the time spent in school as well as time doing homework and participating in extracurricular activities organized by the school). In Tayssir groups, children spent about an extra hour and a half, on average, in school-related activities in the day preceding the survey compared to 2.5 hours spent by children in the control group. Overall, the magnitude of the time use results in Table 6, when compared to those in Table 5, suggests an important intensive margin effect in addition to the extensive margin effect: children in the Tayssir groups spend more time studying and more time physically at 
Table 7-Impacts on Basic Math Skills: Results of ASER Arithmetic Test

\begin{tabular}{|c|c|c|c|c|c|c|c|c|}
\hline & \multirow{2}{*}{$\begin{array}{c}\text { Mean in } \\
\text { control } \\
\text { group } \\
(1)\end{array}$} & \multirow[b]{2}{*}{$\begin{array}{l}\text { Impact of } \\
\text { LCT to } \\
\text { fathers } \\
(2)\end{array}$} & \multicolumn{3}{|c|}{$\begin{array}{l}\text { Difference between }[\ldots] \text { and } \\
\text { LCT to fathers }\end{array}$} & \multirow[b]{2}{*}{$\begin{array}{l}\text { Obs. } \\
(6)\end{array}$} & \multirow{2}{*}{$\begin{array}{l}p \text {-value } \\
\text { for CCT } \\
\text { different } \\
\text { from LCT } \\
\quad(7)\end{array}$} & \multirow{2}{*}{$\begin{array}{l}p \text {-value } \\
\text { for mother } \\
\text { different } \\
\text { from father } \\
\quad(8)\end{array}$} \\
\hline & & & $\begin{array}{l}\text { LCT to } \\
\text { mothers } \\
\text { (3) }\end{array}$ & $\begin{array}{l}\text { CCTs to } \\
\text { fathers } \\
(4)\end{array}$ & $\begin{array}{l}\text { CCTs to } \\
\text { mothers } \\
(5)\end{array}$ & & & \\
\hline \multicolumn{9}{|l|}{ Panel A. All } \\
\hline $\begin{array}{l}\text { Can recognize one-digit } \\
\text { numbers }\end{array}$ & $\begin{array}{c}0.967 \\
{[0.178]}\end{array}$ & $\begin{array}{c}0.009 \\
(0.01)\end{array}$ & $\begin{array}{l}0.01 \\
(0.008)\end{array}$ & $\begin{array}{c}-0.009 \\
(0.009)\end{array}$ & $\begin{array}{c}-0.013 \\
(0.008) *\end{array}$ & 3,316 & $0.003 * * *$ & 0.994 \\
\hline $\begin{array}{l}\text { Can recognize two-digit } \\
\text { numbers }\end{array}$ & $\begin{array}{c}0.91 \\
{[0.287]}\end{array}$ & $\begin{array}{l}0.035 \\
(0.015)^{* *}\end{array}$ & $\begin{array}{c}0.004 \\
(0.015)\end{array}$ & $\begin{array}{l}-0.03 \\
(0.014) * *\end{array}$ & $\begin{array}{l}-0.024 \\
(0.013) *\end{array}$ & 3,316 & $0.003 * * *$ & 0.562 \\
\hline Knows how to subtract & $\begin{array}{c}0.466 \\
{[0.499]}\end{array}$ & $\begin{array}{c}0.054 \\
(0.047)\end{array}$ & $\begin{array}{l}-0.03 \\
(0.048)\end{array}$ & $\begin{array}{c}-0.036 \\
(0.041)\end{array}$ & $\begin{array}{c}-0.043 \\
(0.041)\end{array}$ & 3,316 & 0.383 & 0.588 \\
\hline Knows how to divide & $\begin{array}{c}0.346 \\
{[0.476]}\end{array}$ & $\begin{array}{c}0.022 \\
(0.04)\end{array}$ & $\begin{array}{c}-0.011 \\
(0.042)\end{array}$ & $\begin{array}{c}0.001 \\
(0.036)\end{array}$ & $\begin{array}{c}-0.037 \\
(0.036)\end{array}$ & 3,316 & 0.641 & 0.219 \\
\hline Summary index & $\begin{array}{l}0 \\
{[0.694]}\end{array}$ & $\begin{array}{c}0.081 \\
(0.052)\end{array}$ & $\begin{array}{c}-0.004 \\
(0.05)\end{array}$ & $\begin{array}{c}-0.056 \\
(0.046)\end{array}$ & $\begin{array}{l}-0.081 \\
(0.043) *\end{array}$ & 3,316 & $0.034 * *$ & 0.567 \\
\hline \multicolumn{9}{|c|}{ Panel B. Summary index, by subgroups } \\
\hline Boys & $\begin{array}{l}0 \\
{[0.685]}\end{array}$ & $\begin{array}{c}0.091 \\
(0.059)\end{array}$ & $\begin{array}{c}-0.023 \\
(0.064)\end{array}$ & $\begin{array}{c}-0.058 \\
(0.054)\end{array}$ & $\begin{array}{l}-0.047 \\
(0.055)\end{array}$ & 1,722 & 0.299 & 0.999 \\
\hline Girls & $\begin{array}{l}0 \\
{[0.706]}\end{array}$ & $\begin{array}{c}0.082 \\
(0.073)\end{array}$ & $\begin{array}{c}-0.004 \\
(0.073)\end{array}$ & $\begin{array}{c}-0.081 \\
(0.063)\end{array}$ & $\begin{array}{l}-0.117 \\
(0.061)^{*}\end{array}$ & 1,594 & $0.026 * *$ & 0.585 \\
\hline Main school unit & $\begin{array}{l}0 \\
{[0.698]}\end{array}$ & $\begin{array}{c}0.035 \\
(0.068)\end{array}$ & $\begin{array}{c}0.015 \\
(0.062)\end{array}$ & $\begin{array}{c}-0.052 \\
(0.058)\end{array}$ & $\begin{array}{c}-0.032 \\
(0.055)\end{array}$ & 1,706 & 0.196 & 0.645 \\
\hline Satellite school unit & $\begin{array}{l}0 \\
{[0.691]}\end{array}$ & $\begin{array}{l}0.137 \\
(0.072) *\end{array}$ & $\begin{array}{c}-0.052 \\
(0.074)\end{array}$ & $\begin{array}{c}-0.058 \\
(0.071)\end{array}$ & $\begin{array}{l}-0.126 \\
(0.066)^{*}\end{array}$ & 1,610 & 0.142 & 0.135 \\
\hline $\begin{array}{l}\text { Enrolled in school at baseline } \\
\quad(\text { end of year } 0)\end{array}$ & $\begin{array}{l}0 \\
{[0.686]}\end{array}$ & $\begin{array}{l}0.105 \\
(0.056) *\end{array}$ & $\begin{array}{c}-0.002 \\
(0.052)\end{array}$ & $\begin{array}{c}-0.066 \\
(0.048)\end{array}$ & $\begin{array}{l}-0.079 \\
(0.045)^{*}\end{array}$ & 2,950 & $0.029 * *$ & 0.775 \\
\hline $\begin{array}{l}\text { Out of school at baseline } \\
\text { (end of year } 0)\end{array}$ & $\begin{array}{l}0 \\
{[0.694]}\end{array}$ & $\begin{array}{l}0.066 \\
(0.15)\end{array}$ & $\begin{array}{c}-0.177 \\
(0.176)\end{array}$ & $\begin{array}{c}-0.152 \\
(0.14)\end{array}$ & $\begin{array}{c}-0.195 \\
(0.145)\end{array}$ & 366 & 0.481 & 0.391 \\
\hline
\end{tabular}

Notes: Unit of observation: child. Column 1: standard deviations presented in brackets. Columns 2-5: coefficients and standard errors (in parentheses) from an OLS regression of the left-hand side variable on treatment dummies, controlling for strata dummies and variables specified below. Standard errors are clustered at the school-sector level. Controls included: child age and gender, dummies for child schooling status by June 2008, school was in session at the time of the survey, and same school-level and household-level controls as in Table 5, panel A.

*** Significant at the 1 percent level.

** Significant at the 5 percent level.

* Significant at the 10 percent level.

Source: ASER test administered to (at most) one child aged 6-12 at baseline per household during endline household survey visit. Sampling weights are used since households with dropout children were over-sampled.

the school, as well as more time traveling to and from school, conditional on being enrolled. This extra time spent on learning did not come at the expense of time spent on chores, but in a small part at the expense of household farming or business activities, and in a larger part at the expense of what we call leisure: play and social activities. This suggests that children had spare time to invest in education and thus, in this environment, the barrier to schooling may have had more to do with lack of interest than with severe constraints.

\section{Results: Impacts on Basic Math Skills}

Few studies of conditional cash transfers have measured learning outcomes among school-age children, but when they have, they found no effects, despite increases in participation (Behrman, Parker, and Todd 2005; Filmer and Schady 2009). This 
is in line with many other studies that have been effective at increasing school participation but have found little impact on learning (see Glewwe and Kremer 2006; and Glewwe et al. 2012, for reviews), which raises some questions on the value of promoting school participation without some improvements in school quality. To be able to test the underlying premise behind the Ministry of Education's plan for a cash transfer program, we collected a simple measure of learning achievement, the ASER arithmetic test, that could be administered at home, and thus does not suffer from sample selection due to differential school participation rates across groups. Table 7 shows the impact on performance on the test, which has been administered to one randomly selected child per household during the endline survey. Panel A show the results question by question for all children, as well as results on a standardized measure of achievement on the test, and panel B presents the standardized measures by gender, school type, and baseline enrollment status. There is a modest positive impact of LCT-to-fathers on standardized test scores $(0.08$, which rescaled amounts to $0.08 / 0.694=0.12$ or 12 percent of a standard deviation in the control group), but this effect is not statistically significant in the overall sample (although it is larger and significant for students enrolled at baseline and for those from satellite school units).

Interestingly however, we can rule out equality of the LCT and the CCT impacts: the CCT had significantly smaller impacts than the LCT: while both point estimates for LCT and CCT are insignificant, the difference between CCT and LCT is significant at 5 percent. This may be a statistical fluke (especially given the lack of understanding of the conditionality by parents), or it could be a consequence of the lower rate of re-enrollment of the CCT for children who were perhaps not expected ex ante to meet the conditionality, but in fact met them ex post. Note that this could have been caused by teachers and headmasters making the decisions for parents, even if parents did not understand the rules.

\section{E. Results: Who Did the Program Affect Most?}

Akresh, De Walque, and Kazianga (2013), who compare a purely unconditional cash transfer and a CCT program in Burkina Faso, find insignificant differences, on average, between the programs, but argue that the UCT had smaller effects than the CCT on more "marginal" children: girls, young children, and children of lower ability. To investigate this question in our context, Table 8 shows the main impact of LCT-to-fathers and the effect of all the other versions of the program for these different subgroups (and panel B of Table 7 presents the subgroup results on learning).

Possibly because we consider a labeled unconditional cash transfer program rather than a pure UCT, our results differ from those found by Akresh, de Walque, and Kazianga (2013). First, as mentioned earlier, the impact of the Tayssir LCT on re-enrollment rate for children who had dropped out is significantly larger than the impact of the CCT. Second, although girls have a lower education level than boys (67 percent of girls aged 6-15 were in school at the end of year 2, against 80 percent of boys), the LCT does not have a smaller effect on girls. In fact, if anything it appears that girls are driving the larger impact of LCT than CCT on re-enrollment: for girls who initially dropped out school, the increase in re-enrollment in the LCT-to-fathers 
Table 8-School Participation by Subgroups

\begin{tabular}{|c|c|c|c|c|c|c|c|c|}
\hline & \multirow[b]{2}{*}{$\begin{array}{l}\text { Mean in } \\
\text { control } \\
\text { group } \\
(1)\end{array}$} & \multirow{2}{*}{$\begin{array}{l}\text { Impact of } \\
\text { LCT to } \\
\text { fathers } \\
(2)\end{array}$} & \multicolumn{3}{|c|}{$\begin{array}{c}\text { Difference between }[\ldots] \text { and } \\
\text { LCT to fathers }\end{array}$} & \multirow[b]{2}{*}{$\begin{array}{l}\text { Obs. } \\
(6)\end{array}$} & \multirow{2}{*}{$\begin{array}{c}p \text {-value } \\
\text { for CCT } \\
\text { different } \\
\text { from LCT } \\
\quad(7)\end{array}$} & \multirow{2}{*}{$\begin{array}{l}p \text {-value } \\
\text { for mother } \\
\text { different } \\
\text { from father } \\
\quad(8)\end{array}$} \\
\hline & & & $\begin{array}{l}\text { LCT to } \\
\text { mothers } \\
\text { (3) }\end{array}$ & $\begin{array}{l}\text { CCTs to } \\
\text { fathers } \\
\text { (4) }\end{array}$ & $\begin{array}{l}\text { CCTs to } \\
\text { mothers } \\
(5)\end{array}$ & & & \\
\hline \multicolumn{9}{|c|}{ Panel A. Attending school by end of year 2, among those 6-15 at baseline (household sample) } \\
\hline Boys & $\begin{array}{c}0.802 \\
{[0.399]}\end{array}$ & $\begin{array}{l}0.069 \\
(0.022) * * *\end{array}$ & $\begin{array}{r}-0.001 \\
(0.02)\end{array}$ & $\begin{array}{c}-0.011 \\
(0.016)\end{array}$ & $\begin{array}{c}-0.015 \\
(0.016)\end{array}$ & 4,713 & 0.259 & 0.779 \\
\hline Girls & $\begin{array}{c}0.67 \\
{[0.47]}\end{array}$ & $\begin{array}{l}0.082 \\
(0.02) * * *\end{array}$ & $\begin{array}{c}0.018 \\
(0.02)\end{array}$ & $\begin{array}{c}-0.029 \\
(0.018)\end{array}$ & $\begin{array}{c}-0.017 \\
(0.019)\end{array}$ & 4,522 & $0.012 * *$ & 0.195 \\
\hline Main school unit & $\begin{array}{l}0.75 \\
{[0.433]}\end{array}$ & $\begin{array}{l}0.066 \\
(0.019)^{* * *}\end{array}$ & $\begin{array}{l}0.01 \\
(0.018)\end{array}$ & $\begin{array}{c}-0.022 \\
(0.016)\end{array}$ & $\begin{array}{c}-0.026 \\
(0.016)\end{array}$ & 5,632 & $0.009 * * *$ & 0.99 \\
\hline Satellite school unit & $\begin{array}{c}0.723 \\
{[0.448]}\end{array}$ & $\begin{array}{l}0.086 \\
(0.022)^{* * *}\end{array}$ & $\begin{array}{c}0.004 \\
(0.019)\end{array}$ & $\begin{array}{r}-0.016 \\
(0.016)\end{array}$ & $\begin{array}{c}-0.017 \\
(0.016)\end{array}$ & 5,442 & $0.086^{*}$ & 0.961 \\
\hline $\begin{array}{l}\text { Predicted probability of } \\
\text { school participation } \\
\text { below median }\end{array}$ & $\begin{array}{l}0.523 \\
{[0.5]}\end{array}$ & $\begin{array}{l}0.154 \\
(0.023)^{* * *}\end{array}$ & $\begin{array}{c}0.002 \\
(0.021)\end{array}$ & $\begin{array}{l}-0.038 \\
(0.018)^{* *}\end{array}$ & $\begin{array}{l}-0.039 \\
(0.019) * *\end{array}$ & 5537 & $0.002 * * *$ & 0.943 \\
\hline $\begin{array}{l}\text { Predicted probability of } \\
\text { school participation } \\
\text { above median }\end{array}$ & $\begin{array}{c}0.929 \\
{[0.257]}\end{array}$ & $\begin{array}{c}-0.012 \\
(0.012)\end{array}$ & $\begin{array}{c}0.018 \\
(0.011)\end{array}$ & $\begin{array}{c}0.005 \\
(0.011)\end{array}$ & $\begin{array}{c}0.012 \\
(0.01)\end{array}$ & 5,537 & 0.892 & 0.113 \\
\hline \multicolumn{9}{|c|}{ Panel B. Dropped out by end of year 2, among those enrolled in grades $1-4$ at baseline (household sample) } \\
\hline Boys & $\begin{array}{c}0.083 \\
{[0.277]}\end{array}$ & $\begin{array}{l}-0.069 \\
(0.015)^{* * *}\end{array}$ & $\begin{array}{c}0.011 \\
(0.011)\end{array}$ & $\begin{array}{c}0.021 \\
(0.01) * *\end{array}$ & $\begin{array}{c}0.012 \\
(0.009)\end{array}$ & 3,231 & $0.077 *$ & 0.731 \\
\hline Girls & $\begin{array}{l}0.12 \\
{[0.326]}\end{array}$ & $\begin{array}{l}-0.091 \\
(0.013)^{* * *}\end{array}$ & $\begin{array}{c}-0.019 \\
(0.01)^{*}\end{array}$ & $\begin{array}{c}0.008 \\
(0.01)\end{array}$ & $\begin{array}{c}-0.004 \\
(0.01)\end{array}$ & 2,765 & $0.073^{*}$ & $0.03 * *$ \\
\hline Main school unit & $\begin{array}{c}0.082 \\
{[0.275]}\end{array}$ & $\begin{array}{l}-0.067 \\
(0.014)^{* * *}\end{array}$ & $\begin{array}{c}0.002 \\
(0.011)\end{array}$ & $\begin{array}{l}0.019 \\
(0.01)^{* *}\end{array}$ & $\begin{array}{c}0.013 \\
(0.009)\end{array}$ & 3,070 & $0.024 * *$ & 0.617 \\
\hline Satellite school unit & $\begin{array}{c}0.117 \\
{[0.322]}\end{array}$ & $\begin{array}{l}-0.082 \\
(0.02)^{* * *}\end{array}$ & $\begin{array}{l}-0.02 \\
(0.013)\end{array}$ & $\begin{array}{c}0.008 \\
(0.012)\end{array}$ & $\begin{array}{c}-0.007 \\
(0.012)\end{array}$ & 2,928 & 0.189 & $0.044 * *$ \\
\hline \multicolumn{9}{|c|}{ Panel C. Attending school by end of year 2 if had dropped out at any time before baseline (household sample) } \\
\hline Boys & $\begin{array}{l}0.122 \\
{[0.33]}\end{array}$ & $\begin{array}{l}0.157 \\
(0.099)\end{array}$ & $\begin{array}{c}-0.023 \\
(0.094)\end{array}$ & $\begin{array}{c}0.072 \\
(0.092)\end{array}$ & $\begin{array}{c}0.032 \\
(0.091)\end{array}$ & 449 & 0.232 & 0.426 \\
\hline Girls & $\begin{array}{c}0.161 \\
{[0.369]}\end{array}$ & $\begin{array}{l}0.112 \\
(0.039)^{* * *}\end{array}$ & $\begin{array}{c}0.027 \\
(0.055)\end{array}$ & $\begin{array}{l}-0.106 \\
(0.042) * *\end{array}$ & $\begin{array}{c}-0.071 \\
(0.045)\end{array}$ & 815 & $0.001 * * *$ & 0.255 \\
\hline Main school unit & $\begin{array}{c}0.173 \\
{[0.38]}\end{array}$ & $\begin{array}{l}0.13 \\
(0.069) *\end{array}$ & $\begin{array}{c}-0.043 \\
(0.073)\end{array}$ & $\begin{array}{c}-0.077 \\
(0.067)\end{array}$ & $\begin{array}{c}-0.084 \\
(0.069)\end{array}$ & 639 & 0.216 & 0.736 \\
\hline Satellite school unit & $\begin{array}{c}0.121 \\
{[0.327]}\end{array}$ & $\begin{array}{l}0.145 \\
(0.053) * * *\end{array}$ & $\begin{array}{c}0.042 \\
(0.073)\end{array}$ & $\begin{array}{c}-0.047 \\
(0.053)\end{array}$ & $\begin{array}{c}-0.033 \\
(0.055)\end{array}$ & 625 & 0.121 & 0.489 \\
\hline \multicolumn{9}{|c|}{ Panel D. Attendance rate during surprise school visits, among those enrolled (school sample) } \\
\hline Boys & $\begin{array}{c}0.953 \\
{[0.211]}\end{array}$ & $\begin{array}{c}0.007 \\
(0.01)\end{array}$ & $\begin{array}{c}0.005 \\
(0.009)\end{array}$ & $\begin{array}{c}0.006 \\
(0.008)\end{array}$ & $\begin{array}{c}0.007 \\
(0.008)\end{array}$ & 48,616 & 0.384 & 0.587 \\
\hline Girls & $\begin{array}{l}0.958 \\
{[0.2]}\end{array}$ & $\begin{array}{c}0.006 \\
(0.01)\end{array}$ & $\begin{array}{c}-0.002 \\
(0.009)\end{array}$ & $\begin{array}{c}0.01 \\
(0.007)\end{array}$ & $\begin{array}{c}0.008 \\
(0.008)\end{array}$ & 38,078 & $0.021 * *$ & 0.631 \\
\hline Main school unit & $\begin{array}{c}0.958 \\
{[0.201]}\end{array}$ & $\begin{array}{c}0.001 \\
(0.011)\end{array}$ & $\begin{array}{c}0.000 \\
(0.011)\end{array}$ & $\begin{array}{c}0.007 \\
(0.009)\end{array}$ & $\begin{array}{c}0.01 \\
(0.009)\end{array}$ & 56,262 & 0.122 & 0.744 \\
\hline Satellite school unit & $\begin{array}{c}0.951 \\
{[0.216]}\end{array}$ & $\begin{array}{c}0.021 \\
(0.01)^{* *}\end{array}$ & $\begin{array}{c}0.001 \\
(0.009)\end{array}$ & $\begin{array}{c}0.006 \\
(0.007)\end{array}$ & $\begin{array}{c}0.003 \\
(0.008)\end{array}$ & 30,432 & 0.423 & 0.698 \\
\hline
\end{tabular}

group is 11.2 percentage points and is significant, in the LCT-to-mothers it is 13.9 percentage points and significant, but it is zero in the CCT-to-fathers groups and only 4 percentage points in the CCT-to-mothers group. The difference between LCT and CCT for these girls initially out of school is significant at 1 percent.

In the last two rows of panel A, Table 8, we break down the children in the household sample based on their predicted probability of school participation. This predicted probability is constructed using coefficient estimates of enrollment status on 
Table 8-School Participation by Subgroups (Continued)

\begin{tabular}{|c|c|c|c|c|c|c|c|c|}
\hline & \multirow{2}{*}{$\begin{array}{c}\text { Mean in } \\
\text { control } \\
\text { group } \\
(1)\end{array}$} & \multirow{2}{*}{$\begin{array}{l}\text { Impact of } \\
\text { LCT to } \\
\text { fathers } \\
\text { (2) }\end{array}$} & \multicolumn{3}{|c|}{$\begin{array}{l}\text { Difference between }[\ldots] \text { and } \\
\text { LCT to fathers }\end{array}$} & \multirow[b]{2}{*}{$\begin{array}{l}\text { Obs. } \\
(6)\end{array}$} & \multirow{2}{*}{$\begin{array}{c}p \text {-value } \\
\text { for CCT } \\
\text { different } \\
\text { from LCT } \\
\quad(7)\end{array}$} & \multirow{2}{*}{$\begin{array}{l}p \text {-value } \\
\text { for mother } \\
\text { different } \\
\text { from father } \\
\quad(8)\end{array}$} \\
\hline & & & $\begin{array}{l}\text { LCT to } \\
\text { mothers } \\
\text { (3) }\end{array}$ & $\begin{array}{l}\text { CCTs to } \\
\text { fathers } \\
(4)\end{array}$ & $\begin{array}{l}\text { CCTs to } \\
\text { mothers } \\
(5)\end{array}$ & & & \\
\hline \multicolumn{9}{|c|}{$\begin{array}{l}\text { Panel E. Minutes spent doing any type of schooling activity during the day before survey, children 6-15 at baseline } \\
\text { (household sample) }\end{array}$} \\
\hline Boys & $\begin{array}{c}164.93 \\
{[186.74]}\end{array}$ & $\begin{array}{l}167.62 \\
(51.81)^{* * *}\end{array}$ & $\begin{array}{r}-59.86 \\
(39.02)\end{array}$ & $\begin{array}{l}-48.2 \\
(48.72)\end{array}$ & $\begin{array}{l}-54 \\
(52.61)\end{array}$ & 609 & 0.956 & 0.357 \\
\hline Girls & $\begin{array}{c}114.31 \\
{[164.41]}\end{array}$ & $\begin{array}{c}-16.93 \\
(32.63)\end{array}$ & $\begin{array}{l}76.07 \\
(31.08) * *\end{array}$ & $\begin{array}{l}121.35 \\
(34.72)^{* * *}\end{array}$ & $\begin{array}{c}56.16 \\
(39.49)\end{array}$ & 618 & 0.172 & 0.53 \\
\hline Main school unit & $\begin{array}{c}146.38 \\
{[184.46]}\end{array}$ & $\begin{array}{l}72.49 \\
(48)\end{array}$ & $\begin{array}{c}20.63 \\
(37.5)\end{array}$ & $\begin{array}{l}20 \\
(41.46)\end{array}$ & $\begin{array}{l}23.2 \\
(53.95)\end{array}$ & 647 & 0.895 & 0.867 \\
\hline Satellite school unit & $\begin{array}{l}133.8 \\
{[169.65]}\end{array}$ & $\begin{array}{l}112.08 \\
(34.64) * * *\end{array}$ & $\begin{array}{l}57.89 \\
(31.96) *\end{array}$ & $\begin{array}{c}65.64 \\
(39.17)\end{array}$ & $\begin{array}{c}-54.99 \\
(42.73)\end{array}$ & 580 & 0.955 & 0.149 \\
\hline
\end{tabular}

Notes: Panels A, B, and C: same as Table 5, panel A. Panel D: same as Table 5, panel B. Panel E: same as Table 6.

${ }^{a}$ Predicted probability computed using an OLS regression of endline enrollment on a set of baseline characteristics among the control group. See Table A4 in Appendix.

*** Significant at the 1 percent level.

** Significant at the 5 percent level.

* Significant at the 10 percent level.

school-level, household-level, and child-level characteristics in the control group (these coefficient estimates are shown in Table A4). Not surprisingly, we find that all the program effects on school participation are concentrated among those with a predicted likelihood of school participation below the median. And for those, the effect of the CCT is significantly lower (by 3.8 percentage points, or 25 percent) than that of the LCT. This result, while important in itself, also confirms that despite poor understanding by parents of the specific rules of the programs, it is not the case that the LCT and CCT programs were completely equivalent in practice-if they were, we would not see any difference in impacts. ${ }^{17}$

\section{Mechanisms}

In this section, we provide some additional evidence to shed light on the mechanisms behind these results.

\section{A. Making Education Salient}

Figure 1 shows the dropout rates by cause in the control group, and how they were affected by the program (we only show all the Tayssir groups together for brevity, but there was no significant difference across any of the groups). In the control group, the three main reasons for dropping out of school are accessibility of the

\footnotetext{
${ }^{17}$ Another potential reason why our results differ from that in Akresh, de Walque, and Kazianga (2013) could be a difference in measurement tools. While we have data from repeated spot checks by researchers at the schools, and those match well with the household survey data, Akresh, de Walque, and Kazianga (2013) rely on unverified school reports (they also have household survey reports but those appear very upward biased compared to school reports). School reports are likely to be influenced by conditionality if teachers are reluctant to penalize weaker children. For example, Linden and Shastry (2012) find evidence of systematic misreporting of children attendance by teachers in India.
} 


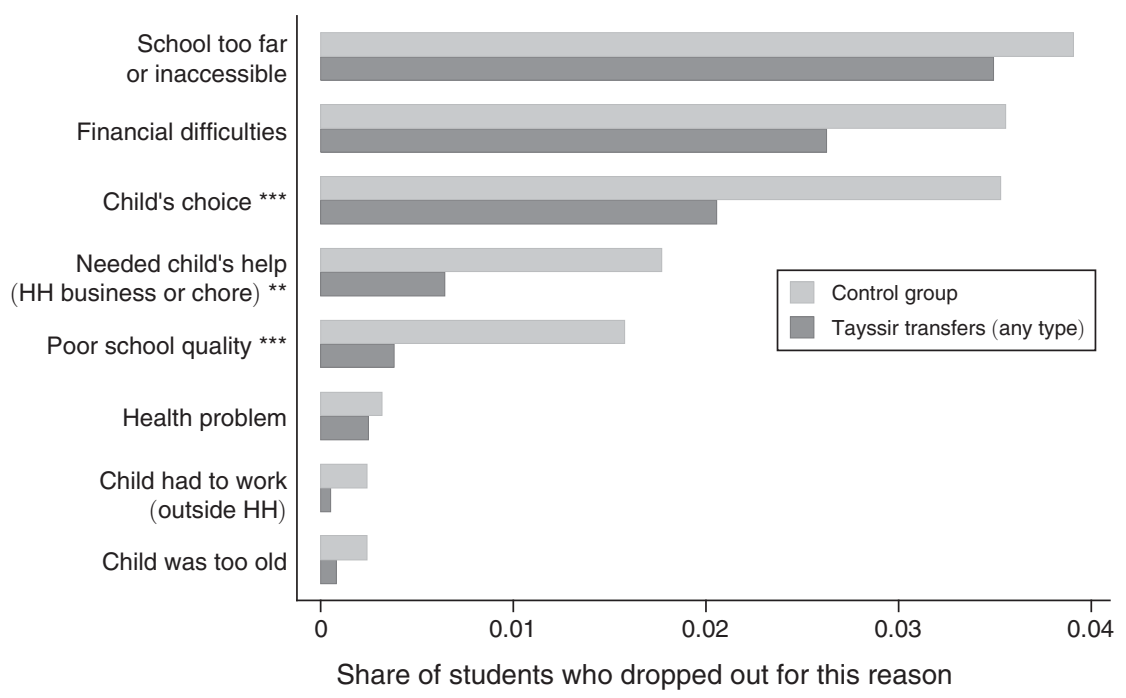

Figure 1. Effect of Tayssir Program on Dropouts, by Cause

Notes: Standard errors are clustered at the school-sector level. The $p$-value for the difference in "financial difficulties" between Tayssir groups and the control group is 0.123 .

*** Significant at the 1 percent level.

** Significant at the 5 percent level.

* Significant at the 10 percent level.

Source: Household survey collected from study households; unit of observation: child; average of 2.5 children per household.

school ("school is too far"), financial reasons, and the fact that the child did not like school ("child's choice"). Tayssir was not designed to affect distance to school and, not surprisingly, did not reduce dropout rates due to distance. In contrast, it reduced the incidence of dropouts due to financial difficulties, though this effect is not quite significant at conventional levels (the $p$-value is 0.123 ). Interestingly, Tayssir had an even larger impact on dropouts due to children simply not wanting to be in school. Also, dropouts due to the belief that school is of poor quality were also considerably reduced by Tayssir. This is surprising, since Tayssir was not accompanied by improvements in school quality and did not include any transfers to schools, therefore leaving school infrastructure quality unchanged. ${ }^{18}$ If anything, the increase in school participation in those schools may have lowered quality, to the extent that class size matters. ${ }^{19}$

One conjecture is that the program, which gave teachers the crucial role of enrolling households, was perceived as an implicit endorsement of the local schools by the Ministry of Education. Table 9 provides further evidence for this. Parents in schools

\footnotetext{
${ }^{18}$ Within the two-year time frame of the Tayssir pilot, there were improvements in school infrastructure through an emergency plan put in place by the Ministry of Education, but, as explained in Section I.C, we were able to stratify by whether a school was scheduled to receive infrastructure support when randomly assigning school sectors to experimental arms.

${ }^{19}$ We can also rule out the possibility that the Tayssir program increased teacher effort or motivation. Overall, we find no program effect on teacher absenteeism. Teachers miss about 10 percent of school days in control schools, which corresponds to an average of 2.5 days in a given month. Teacher attendance was unaffected by the introduction of Tayssir in any form.
} 
Table 9-Mechanisms: Beliefs about Education

\begin{tabular}{|c|c|c|c|}
\hline & $\begin{array}{l}\text { Mean in } \\
\text { control } \\
\text { group } \\
(1)\end{array}$ & $\begin{array}{l}\text { Effect of Tayssir } \\
\text { (any type of } \\
\text { treatment group) } \\
\text { (2) }\end{array}$ & $\begin{array}{l}\text { Obs. } \\
(3)\end{array}$ \\
\hline $\begin{array}{l}\text { At least one parent from the household is a member of the } \\
\text { school board, PTA, or other school association }\end{array}$ & $\begin{array}{c}0.042 \\
{[0.201]}\end{array}$ & $\begin{array}{l}0.01 \\
(0.009)\end{array}$ & 4,026 \\
\hline School quality index ${ }^{\mathrm{a}}$ & $\begin{array}{l}2.569 \\
{[0.67]}\end{array}$ & $\begin{array}{l}0.121 \\
(0.043) * * *\end{array}$ & 4,250 \\
\hline \multicolumn{4}{|l|}{$\begin{array}{l}\text { Parents expected returns to education: } \\
\text { Overall returns: All households }\end{array}$} \\
\hline Increase in income for girls who complete primary school & $\begin{array}{c}-7.654 \\
{[181.436]}\end{array}$ & $\begin{array}{l}17.044 \\
(7.009)^{* *}\end{array}$ & 4,417 \\
\hline $\begin{array}{l}\text { Additional increase in income for girls who complete } \\
\text { junior high school }\end{array}$ & $\begin{array}{c}48.186 \\
{[325.395]}\end{array}$ & $\begin{array}{l}51.04 \\
(16.9)^{* * *}\end{array}$ & 4,383 \\
\hline Increase in income for boys who complete primary school & $\begin{array}{c}91.043 \\
{[585.382]}\end{array}$ & $\begin{array}{c}31.024 \\
(27.995)\end{array}$ & 4,171 \\
\hline $\begin{array}{l}\text { Additional increase in income for boys who complete } \\
\text { junior high school }\end{array}$ & $\begin{array}{l}198.72 \\
{[740.308]}\end{array}$ & $\begin{array}{l}62.064 \\
(37.482)^{*}\end{array}$ & 3,933 \\
\hline \multicolumn{4}{|l|}{ Extensive margin: Probability ${ }^{\mathrm{b}}$ of being employed, once adult, for... } \\
\hline A girl who did not complete primary school & $\begin{array}{c}0.013 \\
{[0.066]}\end{array}$ & $\begin{array}{r}-0.003 \\
(0.003)\end{array}$ & 4,454 \\
\hline A girl who completed primary school & $\begin{array}{c}0.012 \\
{[0.063]}\end{array}$ & $\begin{array}{c}0.002 \\
(0.003)\end{array}$ & 4,454 \\
\hline A girl who completed junior high school & $\begin{array}{c}0.024 \\
{[0.098]}\end{array}$ & $\begin{array}{l}0.012 \\
(0.006)^{* *}\end{array}$ & 4,435 \\
\hline A boy who did not complete primary school & $\begin{array}{c}0.231 \\
{[0.188]}\end{array}$ & $\begin{array}{c}0.000 \\
(0.008)\end{array}$ & 4,423 \\
\hline A boy who completed primary school & $\begin{array}{c}0.244 \\
{[0.185]}\end{array}$ & $\begin{array}{c}-0.007 \\
(0.008)\end{array}$ & 4,389 \\
\hline A boy who completed junior high school & $\begin{array}{c}0.26 \\
{[0.21]}\end{array}$ & $\begin{array}{c}0.011 \\
(0.01)\end{array}$ & 4,317 \\
\hline \multicolumn{4}{|l|}{ Intensive margin: If employed, income in $M A D$, once adult, for. . } \\
\hline A girl who did not complete primary school & $\begin{array}{c}1,177.552 \\
{[738.175]}\end{array}$ & $\begin{array}{c}-180.692 \\
(200.202)\end{array}$ & 165 \\
\hline A girl who completed primary school & $\begin{array}{c}1,101.088 \\
{[546.858]}\end{array}$ & $\begin{array}{l}-48.383 \\
(168.775)\end{array}$ & 202 \\
\hline A girl who completed junior high school & $\begin{array}{c}1,342.461 \\
{[607.484]}\end{array}$ & $\begin{array}{c}7.19 \\
(118.961)\end{array}$ & 402 \\
\hline A boy who did not complete primary school & $\begin{array}{c}1,285.782 \\
{[581.403]}\end{array}$ & $\begin{array}{c}1.909 \\
(37.518)\end{array}$ & 3,192 \\
\hline A boy who completed primary school & $\begin{array}{c}1,343.744 \\
{[608.022]}\end{array}$ & $\begin{array}{c}28.615 \\
(37.788)\end{array}$ & 3,248 \\
\hline A boy who completed junior high school & $\begin{array}{c}1,507.117 \\
{[637.848]}\end{array}$ & $\begin{array}{c}62.936 \\
(36.01)^{*}\end{array}$ & 3,056 \\
\hline
\end{tabular}

Notes: Unit of observation: household. Column 1: standard deviations presented in brackets. Column 2: coefficients and standard errors (in parentheses) from an OLS regression of the left-hand side variable on treatment dummy, controlling for strata dummies and variables specified below. Standard errors are clustered at the school-sector level. All regressions include same household- and school-level controls as in Table 5, panel A.

${ }^{a}$ Average across three school quality indicators. Coded so that 4 reflects highly satisfied, 3 satisfied, 2 dissatisfied, and 1 highly dissatisfied. The three indicators are: infrastructure quality, headmaster availability, and teacher quality.

${ }^{\mathrm{b}}$ Respondents were not asked for a probability between 0 and 1 . They were asked to choose between five categories (no chance, few chances, 50 percent chance, lots of chances, and certain chance). We impute probabilities of $0,0.25,0.5,0.75$, and 1 to these categories, respectively.

*** Significant at the 1 percent level.

** Significant at the 5 percent level.

* Significant at the 10 percent level.

Source: Endline household survey. Sampling weights are used since households with dropout children were over-sampled. 
sampled for the Tayssir program, irrespective of which variant of the program they are in, rank the school quality significantly higher.

Parents may also have interpreted the introduction of a program sponsored by the Ministry of Education as a positive signal about the value of education more generally. Consistent with this, the evidence in Table 9 shows that parental beliefs regarding the returns to education dramatically increased, especially for girls. For girls, the cash transfer programs led to very large positive changes in the perceived returns to education. ${ }^{20}$ In the control group, parents point estimate of the returns to primary school for girls is essentially zero (and if anything negative). There is a large increase in the Tayssir group, and it becomes positive. The perceived returns to secondary school are more than twice as large in the Tayssir group as in the control group. This is driven by changes on the extensive margin - parents in the Tayssir group believe the likelihood of getting employed is higher with primary or junior high school education than parents in the control group. For boys, Tayssir increased the perceive returns to both primary and secondary school by just over 30 percent, but only the effect on secondary school returns is significant, and this effect is a combination of effects on both the extensive and intensive margin.

Several studies (Jensen 2010, 2012; Nguyen 2008) have shown that parents respond to interventions that increase the perceived returns to education by increasing participation and effort in school. Although the Tayssir program was not focused on persuading parents of the returns to education, the impact on the perceived value of education was actually larger in our intervention than in those ones and, as in those, we find an increase in school enrollment.

\section{B. Is a Nudge All That Is Needed?}

To the extent that conditionality had any impact, it was a negative one: the LCT impacts on overall school participation and learning were slightly stronger than the impacts of the CCT. Previous studies have argued that conditionality increases program effects, although as described in the literature review, the results of the two existing randomized studies are nuanced. Akresh et al. (2013) find no difference for the sample as a whole, and Baird et al. (2012) find that UCT has a lower impact on education but higher impact on marriage and early fertility.

In the present case, while the transfers were not conditional on attendance, Tayssir was quite explicitly framed as an education program: headmasters were conducting the enrollment into the program, and the enrollment took place in schools. Thus, while unlabeled unconditional transfers may be less effective at increasing school participation than transfers tied to education, and while strict enforcement of conditionality seems to have additional impact on attendance (Kaufmann, La Ferrara, and Brollo 2012), unconditional but labeled transfers such as the one piloted in Morocco may well provide the nudge that is sufficient to convince parents to send their children to school. While we have not experimented with larger transfers or with finer

\footnotetext{
${ }^{20} \mathrm{We}$ observe this increase in perceived returns among both types of households in our sample (those sampled from the list of enrolled children and those sampled from the list of recent dropouts). The increases are similar in all versions of the programs, so we pool here for precision.
} 
Table 10-Program Costs and Cost-EfFectiveness Analysis

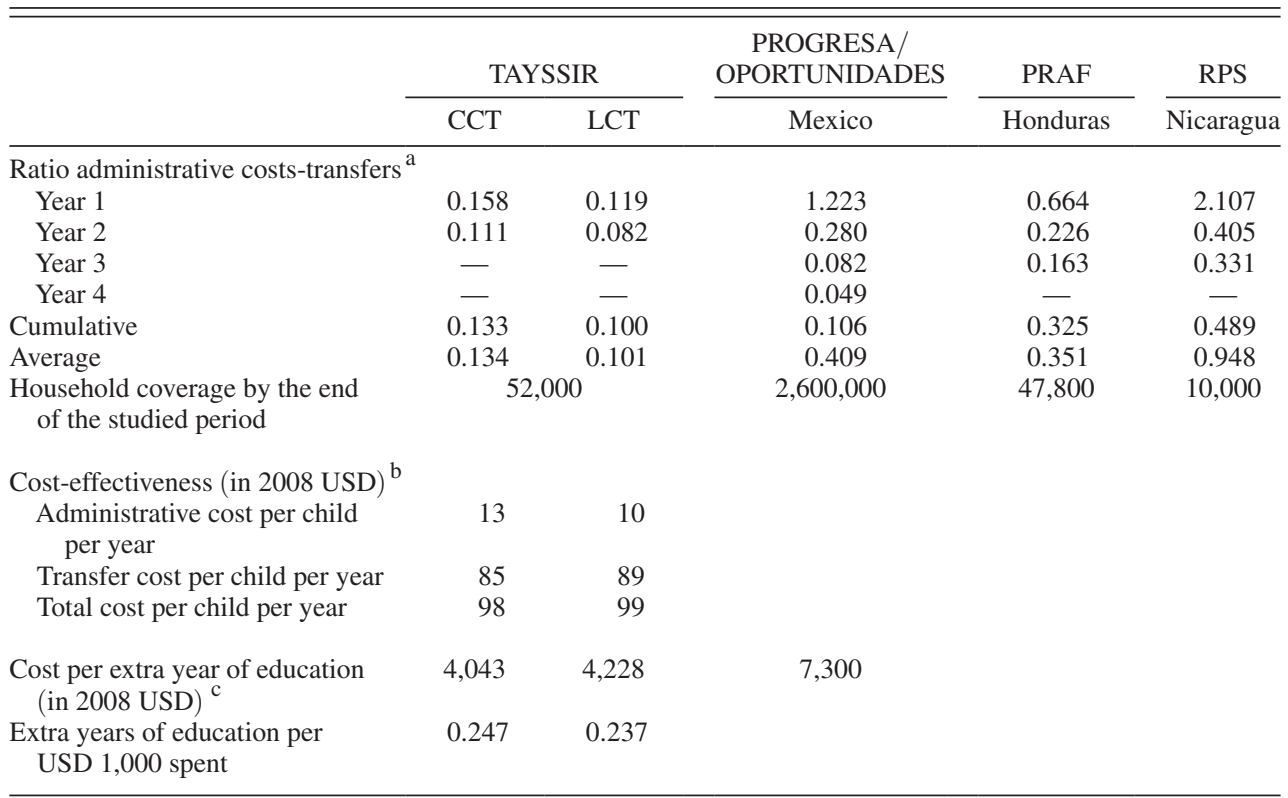

${ }^{a}$ Source: Tayssir: own calculations based on admin. data and estimates provided by the program. Progresa, PRAF, and RPS cost-transfer ratio: Cortes, Coady, and Maluccio (2006), excluding impact evaluation costs.

${ }^{\mathrm{b}}$ Average per child per year over the two-year pilot period of Tayssir. Source: own calculations.

${ }^{\mathrm{c}}$ Tayssir: Computed as present value of total cost divided by present value of extra years of education, over the two-year studied period. Progresa: estimate from Coady (2000).

targeting, it seems that a small transfer targeted only through at the community level was sufficient to achieve a large impact. Thus, the big shove that is provided by the CCT may not be necessary to substantially raise school participation.

In the Moroccan context at least, the nudge has a number of advantages over the shove. First, it is substantially cheaper, both because the transfers per child are smaller and because the administrative costs are lower. If one considers that transfers are not costs (only the deadweight loss of raising the funds for them is a cost), the point is even stronger, because the administrative costs of Tayssir are a fraction of those of the traditional CCT. Table 10 presents a cost-effectiveness analysis of the program. The overall cost of the LCT was $\$ 99$ per child per year (in 2008 US dollars, \$89 in transfers, and \$10 in administrative costs). Compared to the three earlier CCT programs presented in Table 10, Tayssir LCT has the smallest cost-transfer ratio, even relative to PRAF II in Honduras, which had mainly a geographical targeting and small transfers (of 4 percent of household consumption). The cost-effectiveness comparison also favors Tayssir: for the Tayssir LCT program, $\$ 1,000$ led to an increase of 0.24 years of education at the primary level-in other words, the cost of an extra year of education is $\$ 4,228$ in the Tayssir LCT program. For PROGRESA, the cost of an extra year of primary education induced by the CCT is at least 70 percent higher. ${ }^{21}$

\footnotetext{
${ }^{21}$ Coady (2000) estimates the cost of an extra year of primary education, for Progresa, at 55,000 pesos (in 2000 pesos), which is equivalent to around \$7,300 (in 2008 USD). Dhaliwal et al. (2013) estimate an even higher cost per year of education for Progresa.
} 
The second advantage of the nudge over the shove in our context is that the LCT had actually larger impacts on enrollment and days spent in school than the CCT, despite poor understanding of the rules by the parents. This comes from the marginal children-those with a lower propensity to be in school absent any transfers. One likely explanation for this result is that, for people who understand it, the conditionality on attendance may be discouraging: someone who feels like they will not manage to have less than four absences a month may either not enroll or give up under a CCT, but continue under the LCT. Parents in our study context seemed relatively confused about the rules governing the CCT, but this effect could also have come about through the teachers themselves. Indeed, teachers were much more likely to have understood the conditionality, and it is possible that in conditional schools they did not bother to actively seek and enroll into Tayssir the parents of students whom they feel would not regularly attend. Since pupil absenteeism is not a big problem, the incentives based on attendance may thus have discouraged students to enroll without having much bite for those enrolled anyway, making the LCT a better alternative in this context.

Finally, while we did not explicitly compare different ways of targeting households, the very large take-up of Tayssir points to a very important advantage of the geographical targeting used in this study. Indeed, in Indonesia, Alatas et al (2012b) find that in a proxy-means tested program where eligible households must sign-up on their own to enroll and receive benefits, many poor eligible households do not actually sign-up. By removing any ambiguity on eligibility, and putting the responsibility of enrolling households on the teachers, the geographical targeting in the Tayssir program was able to eliminate this problem to a large extent (although as we just discussed not all children enrolled, and some vulnerable children may have been left out in the CCT).

\section{Conclusion}

Through a large-scale randomized experiment conducted jointly with the Moroccan Government, we show that a cash transfer labeled for education and made to households of primary school-age children in rural areas had a very large impact on school participation-despite the fact that the transfer was not conditional on attendance, was given to fathers rather than mothers, and was relatively smallenough to cover the direct costs of education but very small relative to most earlier CCTs as a share of household consumption, even for the poorest households in our sample. These strong results are due in part to an endorsement effect: parents update upwards their beliefs about the value of education when a large pro-education government program enters their community. The cash transfer was labeled for education purposes, since it was coming from the Ministry of Education, and enrollment for the program was administered by school headmasters. In this context, adding formal conditions on attendance tends to decrease the overall impact on participation and learning, and targeting the program to mothers makes no difference.

In a context where pupil absenteeism (conditional on teacher's presence) is negligible for most of the school year, this labeled unconditional cash transfer (LCT) is more cost effective than the standard CCT, both because it requires transfers of 
lower amounts (which may not be counted as costs anyway) and, more importantly, because the administrative costs are much lower. Even in our setting, the administrative costs are reduced by aorund one fourth in the LCT version compared to the CCT, and the conditionality slightly lowers the effect and worsens the targeting. We note that our context is not unique: in Burkina Faso, Akresh, de Walque, and Kazianga (2013) find similarly low rates of absenteeism among enrolled students. In Kenya, Duflo, Dupas, and Kremer (2012) also find very low rates of absenteeism among lower grade students conditional on teacher's presence.

A key question is whether LCT impacts would persist in the long run. To the extent the impacts are due to an increased estimate of the returns to education, longrun impacts will be hampered if the program leads parents to temporarily overestimate those returns. Overoptimistic parents should revert back to their previous levels of investment once they realize that their child's education has not delivered what they had hoped it would. In our survey data, however, parents appear to still underestimate the returns to education, even after the introduction of the program, suggesting that this disappointment effect will be unlikely.

\section{APPENDIX}

Table A1-Balance Check for School Sample

\begin{tabular}{|c|c|c|c|c|c|c|c|c|}
\hline & \multirow{2}{*}{$\begin{array}{l}\text { Mean in } \\
\text { control } \\
\text { group } \\
(1)\end{array}$} & \multirow{2}{*}{$\begin{array}{l}\text { Difference } \\
\text { between } \\
\text { LCT to } \\
\text { fathers and } \\
\text { control } \\
\text { (2) }\end{array}$} & \multicolumn{3}{|c|}{$\begin{array}{c}\text { Difference between }[\ldots] \text { and } \\
\text { LCT to fathers }\end{array}$} & \multirow[b]{2}{*}{$\begin{array}{l}\text { Obs. } \\
(6)\end{array}$} & \multirow{2}{*}{$\begin{array}{c}p \text {-value } \\
\text { for CCT } \\
\text { different } \\
\text { from LCT } \\
\quad(7)\end{array}$} & \multirow{2}{*}{$\begin{array}{l}p \text {-value } \\
\text { for mother } \\
\text { different } \\
\text { from father } \\
\quad(8)\end{array}$} \\
\hline & & & $\begin{array}{l}\text { LCT to } \\
\text { mothers } \\
\text { (3) }\end{array}$ & $\begin{array}{l}\text { CCTs to } \\
\text { fathers } \\
\text { (4) }\end{array}$ & $\begin{array}{l}\text { CCTs to } \\
\text { mothers } \\
(5)\end{array}$ & & & \\
\hline \multicolumn{9}{|c|}{ Panel A. Students' level characteristics at baseline } \\
\hline Age at baseline & $\begin{array}{c}9.742 \\
{[2.115]}\end{array}$ & $\begin{array}{l}0.12 \\
(0.063) *\end{array}$ & $\begin{array}{l}-0.123 \\
(0.071) *\end{array}$ & $\begin{array}{r}-0.064 \\
(0.065)\end{array}$ & $\begin{array}{l}-0.15 \\
(0.065) * *\end{array}$ & 47,255 & 0.295 & $0.026 * *$ \\
\hline Female & $\begin{array}{c}0.426 \\
{[0.495]}\end{array}$ & $\begin{array}{c}-0.003 \\
(0.013)\end{array}$ & $\begin{array}{c}0.019 \\
(0.014)\end{array}$ & $\begin{array}{c}0.013 \\
(0.011)\end{array}$ & $\begin{array}{l}0.02 \\
(0.012) *\end{array}$ & 47,255 & 0.384 & 0.164 \\
\hline $\begin{array}{l}\text { Information on dropout by } \\
\text { year } 2 \text { missing }\end{array}$ & $\begin{array}{c}0.081 \\
{[0.272]}\end{array}$ & $\begin{array}{l}-0.037 \\
(0.015)^{* *}\end{array}$ & $\begin{array}{c}0.031 \\
(0.016) *\end{array}$ & $\begin{array}{l}0.021 \\
(0.012) *\end{array}$ & $\begin{array}{l}0.036 \\
(0.015) * *\end{array}$ & 47,255 & 0.204 & $0.074 *$ \\
\hline \multicolumn{9}{|c|}{$\begin{array}{l}\text { Panel B. Attrition to other schools } \\
\text { (Dependent variable: Moved to another school by the end of year 2, among those enrolled in grades } 1-4 \text { at the end of year } 0 \text { ) }\end{array}$} \\
\hline All & $\begin{array}{c}0.036 \\
{[0.186]}\end{array}$ & $\begin{array}{c}-0.001 \\
(0.005)\end{array}$ & $\begin{array}{l}0.007 \\
(0.007)\end{array}$ & $\begin{array}{c}-0.001 \\
(0.005)\end{array}$ & $\begin{array}{l}0.001 \\
(0.005)\end{array}$ & 38,753 & 0.353 & 0.337 \\
\hline Boys & $\begin{array}{l}0.037 \\
{[0.188]}\end{array}$ & $\begin{array}{l}-0.001 \\
(0.007)\end{array}$ & $\begin{array}{c}0.006 \\
(0.008)\end{array}$ & $\begin{array}{c}-0.005 \\
(0.006)\end{array}$ & $\begin{array}{c}-0.004 \\
(0.006)\end{array}$ & 21,642 & 0.108 & 0.508 \\
\hline Girls & $\begin{array}{c}0.035 \\
{[0.183]}\end{array}$ & $\begin{array}{c}-0.001 \\
(0.006)\end{array}$ & $\begin{array}{c}0.008 \\
(0.007)\end{array}$ & $\begin{array}{c}0.004 \\
(0.005)\end{array}$ & $\begin{array}{c}0.006 \\
(0.005)\end{array}$ & 17,111 & 0.845 & 0.322 \\
\hline Main school unit & $\begin{array}{c}0.039 \\
{[0.194]}\end{array}$ & $\begin{array}{c}-0.007 \\
(0.007)\end{array}$ & $\begin{array}{c}0.012 \\
(0.008)\end{array}$ & $\begin{array}{c}0.004 \\
(0.006)\end{array}$ & $\begin{array}{c}0.005 \\
(0.006)\end{array}$ & 24,989 & 0.671 & 0.257 \\
\hline Satellite school unit & $\begin{array}{l}0.03 \\
{[0.171]}\end{array}$ & $\begin{array}{c}0.007 \\
(0.007)\end{array}$ & $\begin{array}{c}0.000 \\
(0.01)\end{array}$ & $\begin{array}{c}-0.011 \\
(0.006) *\end{array}$ & $\begin{array}{c}-0.006 \\
(0.007)\end{array}$ & 13,764 & 0.107 & 0.535 \\
\hline
\end{tabular}

Notes: Unit of observation: child. Each row presents the results of a separate regression. Column 1: standard deviations presented in brackets. Columns 2-5: coefficients and standard errors (in parentheses) from an OLS regression of the left-hand side variable on treatment dummies, controlling for strata dummies. Columns 7-9 show $p$-values testing that the outcome in each treatment arms are significantly different from those in the control group. Standard errors are clustered at the school-sector level.

*** Significant at the 1 percent level.

** Significant at the 5 percent level.

* Significant at the 10 percent level. 
Table A2-Attrition in Household Sample

\begin{tabular}{|c|c|c|c|c|c|c|c|c|}
\hline & \multirow[b]{2}{*}{$\begin{array}{l}\text { Mean in } \\
\text { control } \\
\text { group } \\
(1)\end{array}$} & \multirow{2}{*}{$\begin{array}{l}\text { Difference } \\
\text { between } \\
\text { LCT to } \\
\text { fathers and } \\
\text { control } \\
\text { (2) }\end{array}$} & \multicolumn{3}{|c|}{$\begin{array}{c}\text { Difference between }[\ldots] \text { and } \\
\text { LCT to fathers }\end{array}$} & \multirow[b]{2}{*}{$\begin{array}{l}\text { Obs. } \\
(6)\end{array}$} & \multirow{2}{*}{$\begin{array}{c}p \text {-value } \\
\text { for CCT } \\
\text { different } \\
\text { from LCT } \\
\quad(7)\end{array}$} & \multirow{2}{*}{$\begin{array}{l}p \text {-value } \\
\text { for mother } \\
\text { different } \\
\text { from father } \\
\quad(8)\end{array}$} \\
\hline & & & $\begin{array}{l}\text { LCT to } \\
\text { mothers } \\
\text { (3) }\end{array}$ & $\begin{array}{l}\text { CCTs to } \\
\text { fathers } \\
(4)\end{array}$ & $\begin{array}{l}\text { CCTs to } \\
\text { mothers } \\
(5)\end{array}$ & & & \\
\hline \multicolumn{9}{|c|}{ Panel A. Attrition from household sample } \\
\hline $\begin{array}{l}\text { Not surveyed at baseline } \\
\text { (as share of households } \\
\text { sampled at baseline) }\end{array}$ & $\begin{array}{c}0.038 \\
{[0.192]}\end{array}$ & $\begin{array}{c}0.000 \\
(0.026)\end{array}$ & $\begin{array}{c}-0.004 \\
(0.028)\end{array}$ & $\begin{array}{c}0.007 \\
(0.024)\end{array}$ & $\begin{array}{c}-0.003 \\
(0.025)\end{array}$ & 5,032 & 0.81 & 0.58 \\
\hline $\begin{array}{l}\text { Not surveyed at endline } \\
\text { (as share of households } \\
\text { surveyed at baseline) }\end{array}$ & $\begin{array}{c}0.123 \\
{[0.328]}\end{array}$ & $\begin{array}{c}-0.036 \\
(0.02)^{*}\end{array}$ & $\begin{array}{c}-0.007 \\
(0.023)\end{array}$ & $\begin{array}{c}0.005 \\
(0.018)\end{array}$ & $\begin{array}{c}-0.001 \\
(0.018)\end{array}$ & 4,832 & 0.653 & 0.609 \\
\hline \multicolumn{9}{|c|}{ Reasons for attrition at endline: } \\
\hline $\begin{array}{l}\text { Household permanently } \\
\text { migrated }\end{array}$ & $\begin{array}{c}0.044 \\
{[0.204]}\end{array}$ & $\begin{array}{l}-0.028 \\
(0.01) * * *\end{array}$ & $\begin{array}{c}0.012 \\
(0.013)\end{array}$ & $\begin{array}{l}0.019 \\
(0.009)^{* *}\end{array}$ & $\begin{array}{l}0.022 \\
(0.009) * * *\end{array}$ & 4,832 & $0.038 * *$ & 0.407 \\
\hline $\begin{array}{l}\text { Household temporarily } \\
\text { migrated }\end{array}$ & $\begin{array}{c}0.028 \\
{[0.164]}\end{array}$ & $\begin{array}{c}-0.004 \\
(0.008)\end{array}$ & $\begin{array}{c}0.002 \\
(0.008)\end{array}$ & $\begin{array}{c}0.005 \\
(0.007)\end{array}$ & $\begin{array}{c}0.001 \\
(0.007)\end{array}$ & 4,832 & 0.728 & 0.675 \\
\hline Refusal & $\begin{array}{c}0.007 \\
{[0.083]}\end{array}$ & $\begin{array}{c}-0.002 \\
(0.005)\end{array}$ & $\begin{array}{c}0.003 \\
(0.005)\end{array}$ & $\begin{array}{c}-0.002 \\
(0.004)\end{array}$ & $\begin{array}{c}0.002 \\
(0.004)\end{array}$ & 4,832 & 0.588 & 0.208 \\
\hline $\begin{array}{l}\text { Household merged with } \\
\text { other study household }\end{array}$ & $\begin{array}{c}0.004 \\
{[0.063]}\end{array}$ & $\begin{array}{c}0.002 \\
(0.004)\end{array}$ & $\begin{array}{c}0.002 \\
(0.005)\end{array}$ & $\begin{array}{c}-0.002 \\
(0.004)\end{array}$ & $\begin{array}{c}-0.003 \\
(0.003)\end{array}$ & 4,832 & 0.121 & 0.991 \\
\hline Household unknown & $\begin{array}{c}0.012 \\
{[0.109]}\end{array}$ & $\begin{array}{c}0.003 \\
(0.007)\end{array}$ & $\begin{array}{c}-0.008 \\
(0.006)\end{array}$ & $\begin{array}{c}-0.001 \\
(0.005)\end{array}$ & $\begin{array}{c}-0.006 \\
(0.005)\end{array}$ & 4,832 & 0.913 & 0.133 \\
\hline $\begin{array}{l}\text { Household location } \\
\text { could not be reach } \\
\text { due to weather } \\
\text { (e.g., flood) }\end{array}$ & $\begin{array}{c}0.025 \\
{[0.156]}\end{array}$ & $\begin{array}{c}-0.003 \\
(0.016)\end{array}$ & $\begin{array}{l}-0.02 \\
(0.014)\end{array}$ & $\begin{array}{r}-0.017 \\
(0.013)\end{array}$ & $\begin{array}{r}-0.019 \\
(0.013)\end{array}$ & 4,832 & 0.242 & 0.241 \\
\hline Other reason & $\begin{array}{c}0.003 \\
{[0.057]}\end{array}$ & $\begin{array}{c}-0.003 \\
(0.002)\end{array}$ & $\begin{array}{c}0.001 \\
(0.002)\end{array}$ & $\begin{array}{c}0.003 \\
(0.002)\end{array}$ & $\begin{array}{c}0.002 \\
(0.002)\end{array}$ & 4,832 & 0.227 & 0.793 \\
\hline \multicolumn{9}{|c|}{ Panel B. Attrition from endline ASER arithmetic test } \\
\hline $\begin{array}{l}\text { Total number of children } \\
\text { tested }\end{array}$ & 600 & 415 & 423 & 921 & 957 & 3,316 & & \\
\hline $\begin{array}{l}\text { Not surveyed at endline } \\
\quad \text { (as share of households } \\
\text { surveyed at baseline })^{\mathrm{a}}\end{array}$ & $\begin{array}{c}0.305 \\
{[0.461]}\end{array}$ & $\begin{array}{c}-0.009 \\
(0.038)\end{array}$ & $\begin{array}{c}0.018 \\
(0.039)\end{array}$ & $\begin{array}{c}0.002 \\
(0.034)\end{array}$ & $\begin{array}{l}-0.03 \\
(0.035)\end{array}$ & 4,682 & 0.307 & 0.455 \\
\hline \multicolumn{9}{|l|}{ Reasons for attrition: } \\
\hline $\begin{array}{l}\text { Household not surveyed } \\
\text { at endline }\end{array}$ & $\begin{array}{c}0.122 \\
{[0.327]}\end{array}$ & $\begin{array}{l}-0.036 \\
(0.021) *\end{array}$ & $\begin{array}{c}-0.006 \\
(0.023)\end{array}$ & $\begin{array}{c}0.003 \\
(0.018)\end{array}$ & $\begin{array}{c}-0.001 \\
(0.018)\end{array}$ & 4,682 & 0.749 & 0.67 \\
\hline $\begin{array}{l}\text { Sampled child not at } \\
\text { home on the day } \\
\text { of the survey }\end{array}$ & $\begin{array}{c}0.127 \\
{[0.333]}\end{array}$ & $\begin{array}{c}0.037 \\
(0.028)\end{array}$ & $\begin{array}{c}-0.009 \\
(0.032)\end{array}$ & $\begin{array}{c}-0.017 \\
(0.026)\end{array}$ & $\begin{array}{c}-0.031 \\
(0.025)\end{array}$ & 4,682 & 0.262 & 0.469 \\
\hline Child or parents refused & $\begin{array}{c}0.029 \\
{[0.169]}\end{array}$ & $\begin{array}{l}-0.018 \\
(0.008)^{* *}\end{array}$ & $\begin{array}{c}0.016 \\
(0.008) *\end{array}$ & $\begin{array}{l}0.017 \\
(0.007)^{* *}\end{array}$ & $\begin{array}{c}0.000 \\
(0.006)\end{array}$ & 4,682 & 0.896 & 0.178 \\
\hline Child migrated & $\begin{array}{c}0.007 \\
{[0.083]}\end{array}$ & $\begin{array}{c}-0.006 \\
(0.005)\end{array}$ & $\begin{array}{c}0.006 \\
(0.004)\end{array}$ & $\begin{array}{l}0.007 \\
(0.004)^{*}\end{array}$ & $\begin{array}{c}0.005 \\
(0.004)\end{array}$ & 4,682 & 0.252 & 0.967 \\
\hline Other reason & $\begin{array}{c}0.02 \\
{[0.14]}\end{array}$ & $\begin{array}{c}0.013 \\
(0.012)\end{array}$ & $\begin{array}{c}0.012 \\
(0.014)\end{array}$ & $\begin{array}{r}-0.008 \\
(0.013)\end{array}$ & $\begin{array}{c}-0.002 \\
(0.011)\end{array}$ & 4,682 & 0.19 & 0.233 \\
\hline
\end{tabular}

Notes: Column 1: standard deviations presented in brackets. Columns 2-5: coefficients and standard errors (in parentheses) from an OLS regression of the left-hand side variable on treatment dummies, controlling for strata dummies. Standard errors are clustered at the school-sector level.

${ }^{a}$ Only child aged 6-12 at baseline were surveyed, so we excluded the 150 households without any 6-12 child at baseline from the ASER sample.

*** Significant at the 1 percent level.

** Significant at the 5 percent level.

* Significant at the 10 percent level.

Source: Baseline and endline household survey 
Table A3-ASER Tests Sample: Balance Check

\begin{tabular}{|c|c|c|c|c|c|c|c|c|}
\hline & \multirow[b]{2}{*}{$\begin{array}{l}\text { Mean in } \\
\text { control } \\
\text { group } \\
(1)\end{array}$} & \multirow{2}{*}{$\begin{array}{l}\text { Difference } \\
\text { between } \\
\text { LCT to } \\
\text { fathers and } \\
\text { control } \\
\text { (2) }\end{array}$} & \multicolumn{3}{|c|}{$\begin{array}{c}\text { Difference between }[\ldots] \text { and } \\
\text { LCT to fathers }\end{array}$} & \multirow[b]{2}{*}{$\begin{array}{l}\text { Obs. } \\
(6)\end{array}$} & \multirow{2}{*}{$\begin{array}{l}p \text {-value for } \\
\text { CCT dif- } \\
\text { ferent from } \\
\text { LCT } \\
(7)\end{array}$} & \multirow{2}{*}{$\begin{array}{c}p \text {-value } \\
\text { for mother } \\
\text { different } \\
\text { from father } \\
\quad(8)\end{array}$} \\
\hline & & & $\begin{array}{l}\text { LCT to } \\
\text { mothers } \\
\text { (3) }\end{array}$ & $\begin{array}{l}\text { CCTs to } \\
\text { fathers } \\
\text { (4) }\end{array}$ & $\begin{array}{l}\text { CCTs to } \\
\text { mothers } \\
(5)\end{array}$ & & & \\
\hline \multicolumn{9}{|c|}{ Panel A. Balance check: Household characteristics (ASER sample) } \\
\hline Head of household is male & $\begin{array}{c}0.967 \\
{[0.178]}\end{array}$ & $\begin{array}{c}0.016 \\
(0.012)\end{array}$ & $\begin{array}{r}-0.007 \\
(0.01)\end{array}$ & $\begin{array}{c}-0.003 \\
(0.009)\end{array}$ & $\begin{array}{c}-0.012 \\
(0.009)\end{array}$ & 3,316 & 0.478 & 0.161 \\
\hline Age of head of household & $\begin{array}{l}45.728 \\
{[9.295]}\end{array}$ & $\begin{array}{l}-1.354 \\
(0.62) * *\end{array}$ & $\begin{array}{l}1.436 \\
(0.645)^{* *}\end{array}$ & $\begin{array}{l}1.321 \\
(0.54)^{* *}\end{array}$ & $\begin{array}{l}1.014 \\
(0.498) * *\end{array}$ & 3,272 & 0.258 & 0.591 \\
\hline $\begin{array}{l}\text { Number of household } \\
\text { members }\end{array}$ & $\begin{array}{c}6.815 \\
{[2.086]}\end{array}$ & $\begin{array}{c}-0.042 \\
(0.152)\end{array}$ & $\begin{array}{c}0.045 \\
(0.162)\end{array}$ & $\begin{array}{r}0.017 \\
(0.14)\end{array}$ & $\begin{array}{c}-0.032 \\
(0.142)\end{array}$ & 3,316 & 0.742 & 0.81 \\
\hline $\begin{array}{l}\text { Number of children } \\
\quad \text { (under 16) }\end{array}$ & $\begin{array}{c}3.251 \\
{[1.274]}\end{array}$ & $\begin{array}{c}0.045 \\
(0.102)\end{array}$ & $\begin{array}{c}-0.134 \\
(0.105)\end{array}$ & $\begin{array}{c}-0.063 \\
(0.096)\end{array}$ & $\begin{array}{c}-0.135 \\
(0.094)\end{array}$ & 3,316 & 0.596 & 0.116 \\
\hline $\begin{array}{l}\text { Percent of children 6-15 } \\
\text { enrolled in school at } \\
\text { baseline }\end{array}$ & $\begin{array}{c}0.797 \\
{[0.269]}\end{array}$ & $\begin{array}{l}0.066 \\
(0.02) * * *\end{array}$ & $\begin{array}{r}-0.024 \\
(0.02)\end{array}$ & $\begin{array}{l}-0.039 \\
(0.018) * *\end{array}$ & $\begin{array}{c}-0.015 \\
(0.017)\end{array}$ & 3,304 & 0.192 & 0.394 \\
\hline $\begin{array}{l}\text { Household head reads and } \\
\text { writes }\end{array}$ & $\begin{array}{l}0.233 \\
{[0.423]}\end{array}$ & $\begin{array}{c}0.042 \\
(0.033)\end{array}$ & $\begin{array}{c}-0.053 \\
(0.034)\end{array}$ & $\begin{array}{c}-0.014 \\
(0.029)\end{array}$ & $\begin{array}{c}-0.035 \\
(0.029)\end{array}$ & 3,269 & 0.908 & 0.126 \\
\hline $\begin{array}{l}\text { Household head completed } \\
\text { primary school }\end{array}$ & $\begin{array}{l}0.042 \\
{[0.2]}\end{array}$ & $\begin{array}{c}0.001 \\
(0.017)\end{array}$ & $\begin{array}{c}-0.012 \\
(0.016)\end{array}$ & $\begin{array}{c}-0.015 \\
(0.013)\end{array}$ & $\begin{array}{c}-0.009 \\
(0.014)\end{array}$ & 3,249 & 0.505 & 0.932 \\
\hline $\begin{array}{l}\text { Household head has at } \\
\text { least some education }\end{array}$ & $\begin{array}{c}0.286 \\
{[0.452]}\end{array}$ & $\begin{array}{c}0.026 \\
(0.035)\end{array}$ & $\begin{array}{l}-0.04 \\
(0.036)\end{array}$ & $\begin{array}{c}0.006 \\
(0.028)\end{array}$ & $\begin{array}{c}-0.031 \\
(0.029)\end{array}$ & 3,258 & 0.726 & $0.06^{*}$ \\
\hline $\begin{array}{l}\text { Per capita consumption } \\
\text { (MAD) }\end{array}$ & $\begin{array}{l}466.714 \\
{[276.734]}\end{array}$ & $\begin{array}{c}15.091 \\
(25.759)\end{array}$ & $\begin{array}{l}-2.391 \\
(30.988)\end{array}$ & $\begin{array}{l}-9.724 \\
(23.022)\end{array}$ & $\begin{array}{c}-17.437 \\
(23.509)\end{array}$ & 3,296 & 0.445 & 0.633 \\
\hline Owns a cellphone & $\begin{array}{c}0.628 \\
{[0.484]}\end{array}$ & $\begin{array}{l}0.124 \\
(0.038)^{* * *}\end{array}$ & $\begin{array}{l}-0.074 \\
(0.037) * *\end{array}$ & $\begin{array}{l}-0.083 \\
(0.028) * * *\end{array}$ & $\begin{array}{l}-0.09 \\
(0.026) * * *\end{array}$ & 3,290 & $0.03 * *$ & 0.202 \\
\hline Owns a television & $\begin{array}{c}0.715 \\
{[0.452]}\end{array}$ & $\begin{array}{c}0.033 \\
(0.051)\end{array}$ & $\begin{array}{c}-0.037 \\
(0.049)\end{array}$ & $\begin{array}{c}-0.024 \\
(0.039)\end{array}$ & $\begin{array}{c}-0.008 \\
(0.038)\end{array}$ & 3,289 & 0.919 & 0.983 \\
\hline Owns a radio & $\begin{array}{c}0.638 \\
{[0.481]}\end{array}$ & $\begin{array}{c}0.025 \\
(0.036)\end{array}$ & $\begin{array}{c}-0.038 \\
(0.035)\end{array}$ & $\begin{array}{c}-0.018 \\
(0.027)\end{array}$ & $\begin{array}{l}-0.069 \\
(0.03) * *\end{array}$ & 3,289 & 0.235 & $0.029 * *$ \\
\hline Main occupation: Farming & $\begin{array}{c}0.627 \\
{[0.484]}\end{array}$ & $\begin{array}{c}0.018 \\
(0.049)\end{array}$ & $\begin{array}{l}-0.01 \\
(0.052)\end{array}$ & $\begin{array}{c}0.024 \\
(0.043)\end{array}$ & $\begin{array}{c}-0.023 \\
(0.044)\end{array}$ & 3,233 & 0.847 & 0.181 \\
\hline Owns a bank account & $\begin{array}{c}0.032 \\
{[0.176]}\end{array}$ & $\begin{array}{c}0.016 \\
(0.019)\end{array}$ & $\begin{array}{l}0 \\
(0.019)\end{array}$ & $\begin{array}{c}-0.008 \\
(0.017)\end{array}$ & $\begin{array}{c}-0.011 \\
(0.018)\end{array}$ & 3,288 & 0.396 & 0.883 \\
\hline Household has electricity & $\begin{array}{c}0.548 \\
{[0.498]}\end{array}$ & $\begin{array}{c}0.056 \\
(0.072)\end{array}$ & $\begin{array}{r}-0.013 \\
(0.07)\end{array}$ & $\begin{array}{c}-0.054 \\
(0.062)\end{array}$ & $\begin{array}{c}0.03 \\
(0.06)\end{array}$ & 3,316 & 0.891 & 0.16 \\
\hline \multicolumn{9}{|c|}{ Panel B. Balance check: Children characteristics (ASER sample) } \\
\hline Age in 2008 & $\begin{array}{c}9.454 \\
{[1.701]}\end{array}$ & $\begin{array}{c}0.033 \\
(0.124)\end{array}$ & $\begin{array}{c}-0.098 \\
(0.131)\end{array}$ & $\begin{array}{c}-0.033 \\
(0.101)\end{array}$ & $\begin{array}{c}-0.045 \\
(0.106)\end{array}$ & 3,316 & 0.889 & 0.577 \\
\hline Female & $\begin{array}{c}0.454 \\
{[0.498]}\end{array}$ & $\begin{array}{c}0.021 \\
(0.031)\end{array}$ & $\begin{array}{c}0.025 \\
(0.036)\end{array}$ & $\begin{array}{c}0.022 \\
(0.028)\end{array}$ & $\begin{array}{c}-0.002 \\
(0.028)\end{array}$ & 3,316 & 0.909 & 0.643 \\
\hline $\begin{array}{l}\text { Enrolled in primary } \\
\text { school in } 2008\end{array}$ & $\begin{array}{c}0.877 \\
{[0.329]}\end{array}$ & $\begin{array}{l}0.056 \\
(0.018) * * *\end{array}$ & $\begin{array}{l}-0.035 \\
(0.019) *\end{array}$ & $\begin{array}{l}-0.033 \\
(0.017)^{*}\end{array}$ & $\begin{array}{c}-0.016 \\
(0.015)\end{array}$ & 3,240 & 0.554 & 0.935 \\
\hline $\begin{array}{l}\text { Ever enrolled in primary } \\
\text { school in } 2008\end{array}$ & $\begin{array}{c}0.928 \\
{[0.259]}\end{array}$ & $\begin{array}{l}0.043 \\
(0.014) * * *\end{array}$ & $\begin{array}{r}-0.025 \\
(0.016)\end{array}$ & $\begin{array}{c}-0.005 \\
(0.012)\end{array}$ & $\begin{array}{c}-0.002 \\
(0.11)\end{array}$ & 3,241 & 0.311 & 0.5 \\
\hline
\end{tabular}

Notes: Column 1: standard deviations presented in brackets. Columns 2-5: coefficients and standard errors (in parentheses) from an OLS regression of the left-hand side variable on treatment dummies, controlling for strata dummies. Standard errors are clustered at the school-sector level.

*** Significant at the 1 percent level.

** Significant at the 5 percent level.

* Significant at the 10 percent level.

Source: Baseline household survey 
Table A4-Determinants of School Participation in the Control Group

\begin{tabular}{|c|c|}
\hline & Attending school by the end of year 2 \\
\hline \multicolumn{2}{|l|}{ Individual characteristics } \\
\hline Female & $\begin{array}{c}-0.133^{* * * *} \\
(0.025)\end{array}$ \\
\hline Age at baseline & $\begin{array}{l}-0.054^{* * * *} \\
(0.020)\end{array}$ \\
\hline \multicolumn{2}{|l|}{ Household characteristics } \\
\hline Household head is a male & $\begin{array}{c}0.050 \\
(0.096)\end{array}$ \\
\hline Age of household head & $\begin{array}{c}-0.003^{* *} \\
(0.001)\end{array}$ \\
\hline Age of household head spouse & $\begin{array}{c}-0.002 * \\
(0.001)\end{array}$ \\
\hline Household head speaks Amazygh & $\begin{array}{c}0.032 \\
(0.035)\end{array}$ \\
\hline Household head can read and write & $\begin{array}{l}-0.001 \\
(0.027)\end{array}$ \\
\hline Household head spouse can read and write & $\begin{array}{c}0.057 \\
(0.042)\end{array}$ \\
\hline Perceived school quality at baseline (index) ${ }^{\mathrm{a}}$ & $\begin{array}{c}0.003 \\
(0.016)\end{array}$ \\
\hline $\begin{array}{l}\text { Agreed to the statement: "Children are losing their } \\
\text { time in school" }\end{array}$ & $\begin{array}{c}0.017 \\
(0.030)\end{array}$ \\
\hline Number of household members & $\begin{array}{r}-0.003 \\
(0.007)\end{array}$ \\
\hline Number of children in the household & $\begin{array}{r}-0.017 \\
(0.012)\end{array}$ \\
\hline Number of females in the household & $\begin{array}{r}-0.000 \\
(0.011)\end{array}$ \\
\hline Number of rooms in the house & $\begin{array}{r}-0.007 \\
(0.006)\end{array}$ \\
\hline House is mainly made of stone & $\begin{array}{r}-0.009 \\
(0.020)\end{array}$ \\
\hline Household owns a TV & $\begin{array}{r}-0.044 \\
(0.029)\end{array}$ \\
\hline Household owns a cellphone & $\begin{array}{c}0.029 \\
(0.026)\end{array}$ \\
\hline Household owns agricultural land & $\begin{array}{c}0.022 \\
(0.021)\end{array}$ \\
\hline Household owns a fridge & $\begin{array}{c}0.023 \\
(0.023)\end{array}$ \\
\hline Someone in the household has a bank account & $\begin{array}{r}-0.020 \\
(0.052)\end{array}$ \\
\hline Household house has electricity & $\begin{array}{l}0.083 * * \\
(0.032)\end{array}$ \\
\hline Household monthly per capita consumption & $\begin{array}{c}-0.002 \\
(0.004)\end{array}$ \\
\hline
\end{tabular}

(Continued) 
Table A4-Determinants of School Participation IN The Control Group (Continued)

\begin{tabular}{lc}
\hline \hline & Attending school by the end of year 2 \\
\hline School characteristics & 0.004 \\
Satellite school & $(0.022)$ \\
& -0.050 \\
School in the village has electricity & $(0.037)$ \\
& $-0.064^{* *}$ \\
School in the village inaccessible during winter & $(0.029)$ \\
& -0.027 \\
School in the village has toilet & $(0.025)$ \\
& \\
Observations & 2,001 \\
$R^{2}$ & 0.222 \\
Mean dependent variable & 0.737 \\
\hline
\end{tabular}

Notes: Unit of observation: child. Linear probability model controlling for strata dummies. Standard errors are clustered at the school-sector level.

${ }^{a}$ Average across three school quality indicators. Coded so that 4 reflects highly satisfied, 3 satisfied, 2 dissatisfied, and 1 highly dissatisfied. The three indicators are: infrastructure quality, headmaster availability, and teacher quality.

*** Significant at the 1 percent level.

** Significant at the 5 percent level.

* Significant at the 10 percent level.

Source: Household surveys. Sampling weights are used since households with dropout children were over-sampled.

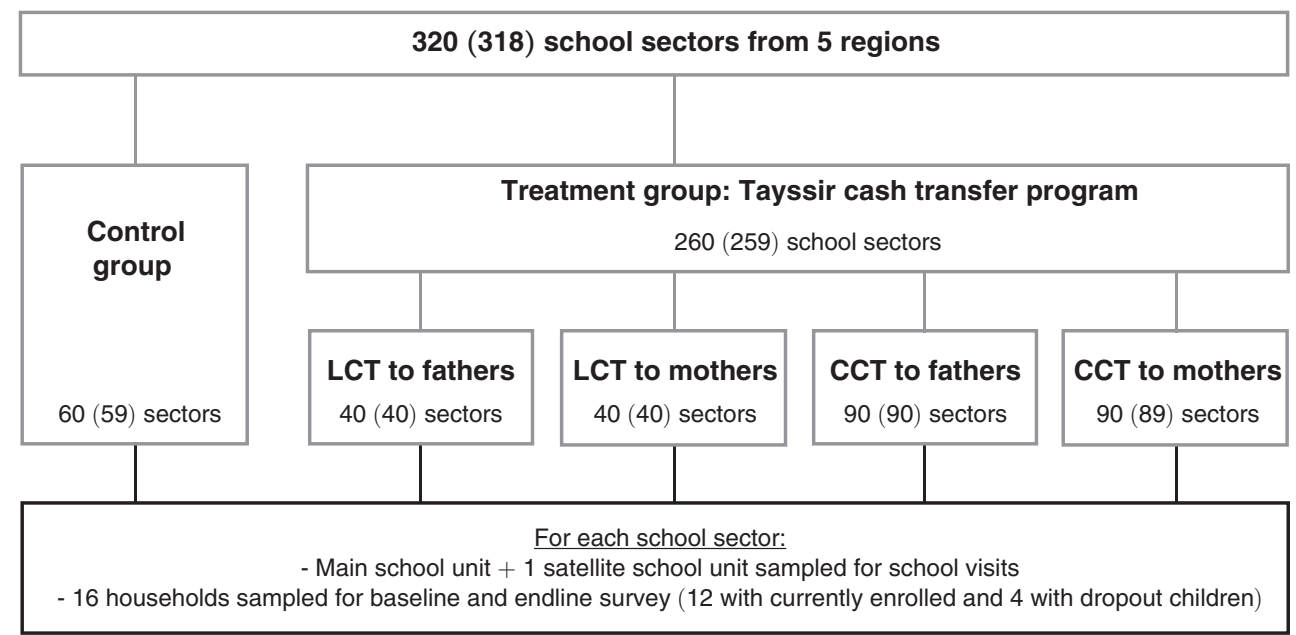

\section{Figure A1. Experimental Design}

Notes: Sample size $X(Y)$ indicates the initial (realized) sample size. The realized sample size is slightly smaller than the initial sample size due to two school sectors that couldn't be reached at baseline due to floods. CCT stands for Conditional Cash Transfer. The condition was "no more than four absences in the month." LCT stands for Labeled (unconditional) Cash Transfer. See Section ID of paper for details on the amounts of the transfers. 


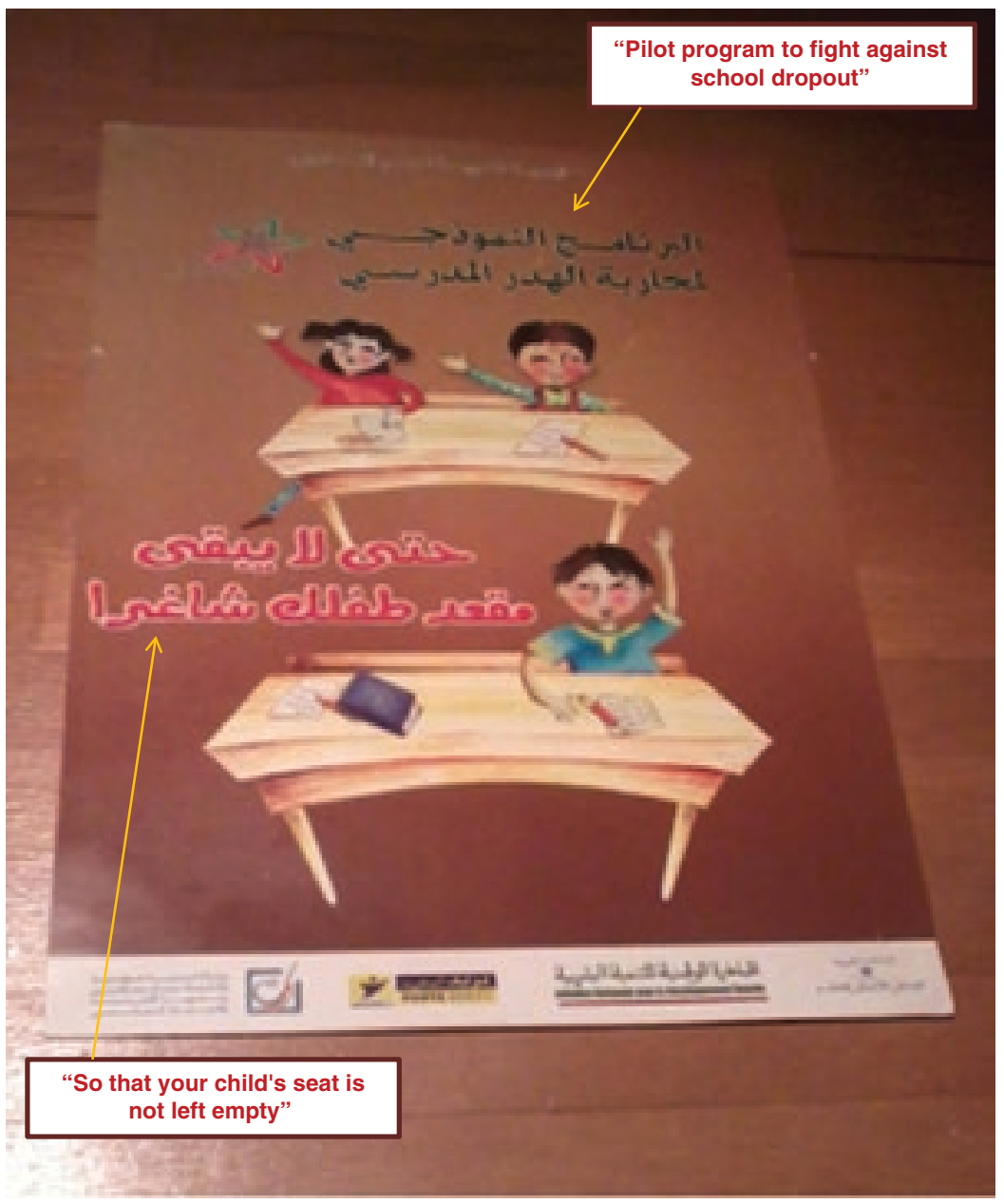

FIgUre A2. TAYsSIR Poster 


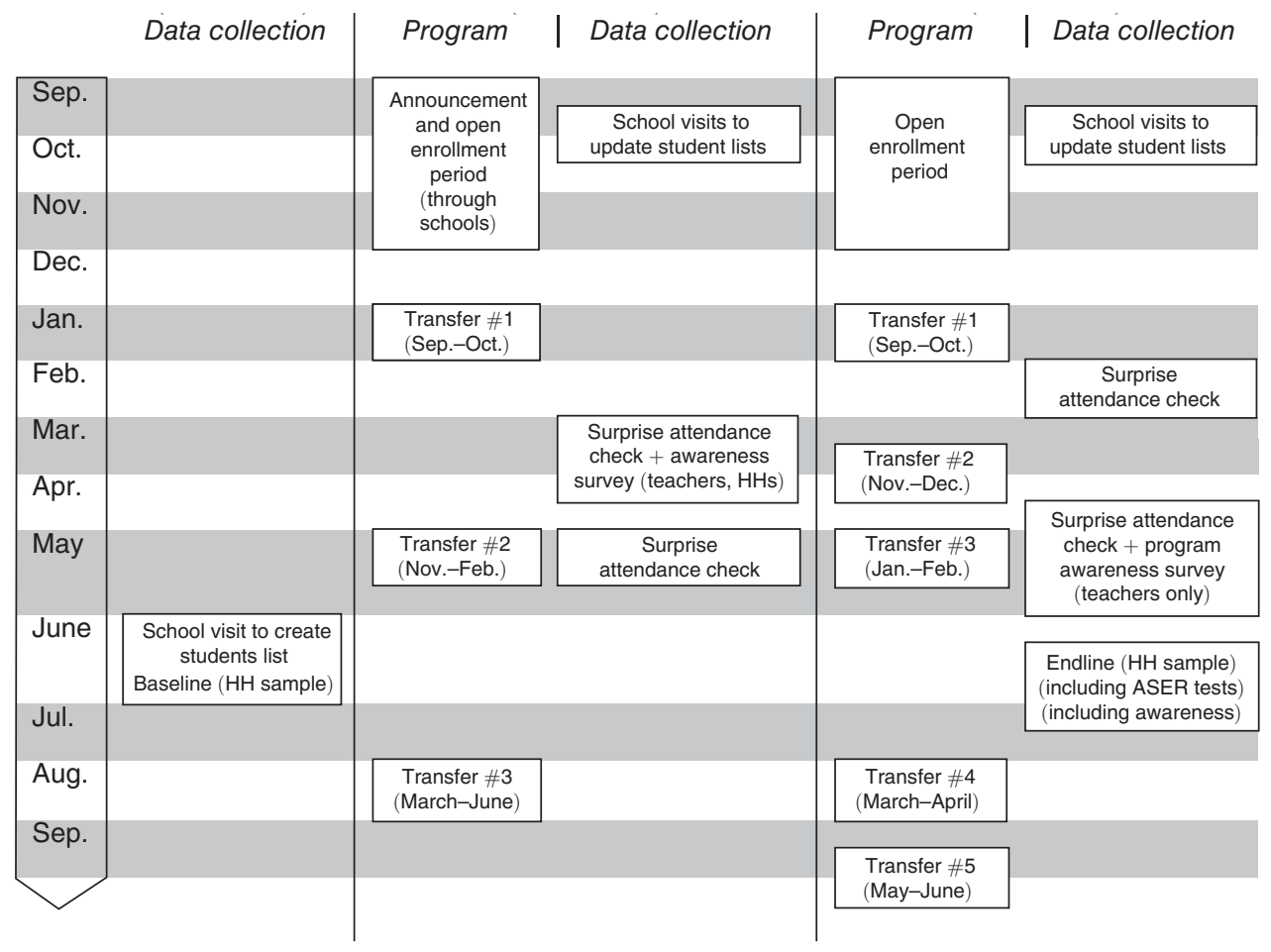

Figure A3. Timeline

\section{REFERENCES}

Alatas, Vivi, Abhijit Banerjee, Rema Hanna, Ben Olken, and Julia Tobias. 2012a. "Targeting the Poor: Evidence from a Field Experiment in Indonesia." American Economic Review 102 (4): 1206-40.

Alatas, Vivi, Ben Olken, Abhijit Banerjee, Rema Hanna, Ririn Purnamasari, and Matthew Wai-Poi. 2012b. "Ordeal Mechanisms in Targeting: Theory and Evidence from a Field Experiment in Indonesia." Unpublished.

Akresh, Richard, Damien de Walque, and Harounan Kazianga. 2013. "Cash Transfers and Child Schooling: Evidence from a Randomized Evaluation of the Role of Conditionality." World Bank Policy Research Working Paper 6340.

Attanasio, Orazio, Costas Meghir, and Ana Santiago. Forthcoming. "Education Choices in Mexico: Using a Structural Model and a Randomized Experiment to Evaluate PROGRESA." Review of Economic Studies.

Attanasio, Orazio, Veruska Oppedisano, and Marcos Vera-Hernández. 2013. "Conditionality, Preventative Care and Health: Evidence from Colombia." Unpublished.

Banerjee, Abhijit, Esther Duflo, Abdul Latif Jameel, Rachel Glennerster, and Dhruva Kothari. 2010. "Improving Immunization Coverage in Rural India: A Clustered Randomized Controlled Evaluation of Immunization Campaigns with and without Incentives.” British Medical Journal 340: c2220.

Baird, Sarah, Francisco H. G. Ferreira, Berk Özler, and Michael Woolcock. 2013. "Relative Effectiveness of Conditional and Unconditional Cash Transfers for Schooling Outcomes in Developing Countries: A Systematic Review.” Campbell Systematic Reviews 9 (8): 1-124.

-Baird, Sarah, Craig McIntosh, and Berk Özler. 2011. "Cash or Condition? Evidence from a Randomized Cash Transfer Program.” Quarterly Journal of Economics 126 (4): 1709-53.

-Barrera-Osorio, Felipe, Marianne Bertrand, Leigh L. Linden, and Francisco Perez. 2011. "Improving the Design of Conditional Transfer Programs: Evidence from a Randomized Education Experiment in Colombia." American Economic Journal: Applied Economics 3 (2): 167-95.

Behrman, Jere R., Susan W. Parker, and Petra E. Todd. 2005. "Long-Term Impacts of the Oportunidades Conditional Cash Transfer Program on Rural Youth in Mexico.” Ibero-America Institute for Economic Research Discussion Paper 122. 
Benhassine, Najy, Florencia Devoto, Esther Duflo, Pascaline Dupas, and Victor Pouliquen. 2015. "Turning a Shove into a Nudge? A 'Labeled Cash Transfer' for Education: Dataset." American Economic Journal: Economic Policy. http://dx.doi.org/10.1257/pol.20130225.

-Bourguignon, François, Francisco H. G. Ferreira, and Phillippe G. Leite. 2003. "Conditional Cash Transfers, Schooling, and Child Labor: Micro-Simulating Brazil's Bolsa Escola Program.” World Bank Economic Review 17 (2): 229-54.

Caldés, Natàlia, David Coady, and John A. Maluccio. 2006. "The cost of poverty alleviation transfer programs: A comparative analysis of three programs in Latin America." World Development 34 (5): 818-37.

Coady, David P. 2000. The Application of Social Cost-Benefit Analysis to the Evaluation of PROGRESA. International Food Policy Research Institute. Washington, DC, November.

Dhaliwal, Iqbal, Esther Duflo, Rachel Glennerster, and Caitlin Tulloch. 2013. "Comparative Cost-Effectiveness Analysis to Inform Policy in Developing Countries: A General Framework with Applications for Education." In Education Policy in Developing Countries, edited by Paul Glewwe, 285-338. Chicago: University of Chicago Press.

De Brauw, Alan, and John Hoddinott. 2011. "Must conditional cash transfer programs be conditioned to be effective? The impact of conditioning transfers on school enrollment in Mexico." Journal of Development Economics 96 (2): 359-70.

Duflo, Esther, Pascaline Dupas, and Michael Kremer. 2012. "School Governance, Teacher Incentives, and Pupil-Teacher Ratios: Experimental Evidence from Kenyan Primary Schools.” National Bureau of Economic Research (NBER) Working Paper 17939.

Edmonds, Eric. 2002. "Reconsidering the Labeling Effect for Child Benefits: Evidence from a Transition Economy." Economic Letters 76 (3): 303-09.

-Edmond, Eric V., and Norbert Schady. 2012. "Poverty Alleviation and Child Labor." American Economic Journal: Economic Policy 4 (4): 100-124.

Filmer, Deon, and Norbert Schady. 2008. "Getting Girls into School: Evidence from a Scholarship Program in Cambodia." Economic Development and Cultural Change 56 (3): 581-617.

Filmer, Deon, and Norbert Schady. 2009. "School Enrollment, Selection and Test Scores.” World Bank Policy Research Working Paper 4998.

Fizbein, Ariel, Norbert Schady, Francisco H. G. Ferreira, Margaret Grosh, Niall Keleher, Pedro Olinto, Emmanuel Skoufias. 2009. Conditional Cash Transfers: Reducing Present and Future Poverty. Washington, DC: World Bank.

Glewwe, Paul, Eric Hanushek, Sarah Humpage, and Renato Ravina. 2012. "School Resources and Educational Outcomes in Developing Countries: A Review of the Literature from 1990 to 2010." University of Minnesota Center for International Food and Agricultural Policy Working Paper 12-1.

Glewwe, Paul, and Michael Kremer. 2006. "Schools, Teachers, and Education Outcomes in Developing Countries." In Handbook of the Economics of Education, Vol. 2, edited by E. Hanushek and F. Welch, 945-1017. Amsterdam: North-Holland.

-Jensen, Robert. 2010. "The (Perceived) Returns to Education and the Demand for Schooling." Quarterly Journal of Economics 125 (2): 515-48.

-Jensen, Robert. 2012. "Do Labor Market Opportunities Affect Young Women's Work and Family Decisions? Experimental Evidence from India.” Quarterly Journal of Economics 127 (2): 753-92.

Kaufmann, Katja. 2012. "Understanding the Income Gradient in College Attendance in Mexico: The Role of Heterogeneity in Expected Returns." Unpublished.

Kaufmann, Katja Maria, Eliana La Ferrara, and Fernanda Brollo. 2012. "Learning about the Enforcement of Conditional Welfare Programs: Evidence from the Bolsa Familia Program in Brazil.” http:// fakultaetsseminar.uni-mannheim.de/material/PaperKaufmann.pdf.

-Linden, Leigh L., and Gauri Kartini Shastry. 2012. "Grain inflation: Identifying agent discretion in response to a conditional school nutrition program." Journal of Development Economics 99 (1): $128-38$.

Nguyen, Trang. 2008. "Information, Role Models and Perceived Returns to Education: Experimental Evidence from Madagascar." http://www.povertyactionlab.org/doc/information-role-models-andperceived-returns-education.

Saavedra, Juan Esteban, and Sandra García. 2012. "Impacts of Conditional Cash Transfer Programs on Educational Outcomes in Developing Countries: A Meta-analysis." http://www.rand.org/ content/dam/rand/pubs/working_papers/2012/RAND_WR921-1.pdf.

Schady, Norbert, and María Caridad Araujo. 2008. "Cash Transfers, Conditions, and School Enrollment in Ecuador." Economía 8 (2): 43-70.

Thaler, Richard. 1990. "Savings, Fungibility, and Mental Accounts." Journal of Economic Perspectives 4 (1): 193-205. 
This article has been cited by:

1. George Bulman. 2015. The Effect of Access to College Assessments on Enrollment and Attainment. American Economic Journal: Applied Economics 7:4, 1-36. [Abstract] [View PDF article] [PDF with links] 